\title{
$1 \quad$ Impact history of the Apollo 17 landing site revealed by U-Pb SIMS ages
}

2 F. Thiessen $^{1 *}$, A. A. Nemchin ${ }^{1,2}$, J. F. Snape ${ }^{1}$, M. J. Whitehouse ${ }^{1}$, J. J. Bellucci ${ }^{1}$

$3{ }^{1}$ Department of Geosciences, Swedish Museum of Natural History, SE-104 05 Stockholm,

4 Sweden

$5 \quad{ }^{2}$ Department of Applied Geology, Curtin University, Perth, WA 6845, Australia

$6 \quad *$ Corresponding author, Fiona.Thiessen@nrm.se

Abstract

Secondary ion mass spectrometry (SIMS) U-Pb ages of Ca-phosphates from four texturally distinct breccia samples $(72255,76055,76015,76215)$ collected at the Apollo 17 landing site were obtained in an attempt to identify whether they represent a single or several impact event(s). The determined ages, combined with inferences from petrologic relationships, may indicate two or possibly three different impact events at 3920 $\pm 3 \mathrm{Ma}, 3922 \pm 5 \mathrm{Ma}$ and 3930 \pm 5 Ma (all errors 2 $\sigma$ ). Searching for possible sources of the breccias by calculating the continuous ejecta radii of impact basins and large craters as well as their expected ejecta thicknesses, we conclude that Nectaris, Crisium, Serenitatis and Imbrium are likely candidates. If the previous interpretation that the micropoikilitic breccias collected at the North Massif represent Serenitatis ejecta is correct, then the average ${ }^{207} \mathrm{~Pb} /{ }^{206} \mathrm{~Pb}$ age of $3930 \pm 5 \mathrm{Ma}(2 \sigma)$ dates the formation of the Serenitatis basin. The occurrence of zircon in the breccias sampled at the South Massif, which contain Ca-phosphates yielding an age of $3922 \pm 5$ Ma $(2 \sigma)$, may indicate that the breccia originated from within the Procellarum KREEP terrane (PKT) and the Imbrium basin appears to be the only basin that could have sourced them. However, this interpretation implies that all basins suggested to fall stratigraphically between Serenitatis and Imbrium formed within a short ( $<11 \mathrm{Ma}$ ) time interval, highlighting serious contradictions between global stratigraphic constraints, sample interpretation and chronological data. Alternatively, the slightly older age of the two micropoikilitic breccias may be a result of incomplete resetting of the U-Pb system preserved in some phosphate grains. Based on the currently available dataset this possibility cannot be excluded. 


\section{Introduction}

One of the main objectives of the Apollo 17 mission in 1972 was to sample highland materials older than the Imbrium impact, since Imbrium ejecta was already thought to be present in some of the Apollo 12, 14 and 15 samples (e.g. Hinners, 1973). To this end, the Taurus-Littrow Valley, located at the edge of the Serenitatis impact basin and south of the Taurus Mountains and the crater Littrow, was chosen as it offered the possibility to determine the age of the Serenitatis impact. The Serenitatis basin was determined to be older than the Imbrium basin based on its degradation, as inferred from remote sensing data (e.g. Wilhelms et al., 1971).

Prior to the mission, several geological interpretations of the origin of the Taurus-Littrow highlands material had been proposed. The highland samples collected during the Apollo 14, 15 and 16 missions consisted mainly of impact breccias and the Taurus-Littrow highlands were thought to be comprised of similar materials (Scott et al., 1972). Scott et al. (1972) interpreted these materials to originate from the Serenitatis impact and to be mixed with preSerenitatis breccias, while Head (1974a) inferred that the Littrow massif exhibits primarily Serenitatis impact breccias and bottom layers of pre-Serenitatis impact breccias which were uplifted during the Serenitatis impact. Moreover, the massifs could have been covered by post-Serenitatis impact ejecta, e.g. from the Imbrium or Crisium impact (Head, 1974a). McGetchin et al. (1973) estimated the Serenitatis impact layer to have an average thickness of $\sim 1655 \mathrm{~m}$ at the Apollo 17 landing site, overlain by a thinner layer of post-Serenitatis impact ejecta $(\sim 224 \mathrm{~m})$.

The returned breccia samples consist of four different textual impact breccia types: (1) granulitic, (2) poikilitic, (3) micropoikilitic-subophitic and (4) aphanitic (Simonds et al., 1974). Poikilitic breccias were sampled on both the North and South Massifs. Aphanitic breccias were mainly found at the South Massif (Ryder, 1993), although, Jolliff et al. (1996) found some lithic fragments belonging to the aphanitic-matrix breccias in the Station 6 boulder at the North Massif. These two different breccia types were initially interpreted to represent impact melts produced by the same impact, possibly Serenitatis (Wolfe et al., 1981), although the aphanitic breccias exhibit significant petrological and chemical differences compared to the poikilitic breccias (Spudis et al., 1981). In general, the aphanitic breccias have a finer grain size, a larger number of clasts, are darker in color and lack vesicles. The aphanitic breccias also have lower $\mathrm{TiO}_{2}, \mathrm{Na}_{2} \mathrm{O}, \mathrm{Eu}$ and $\mathrm{Sr}$ concentrations compared to the poikilitic breccias (Spudis et al., 1981; Jolliff et al., 1996). Nevertheless, Wood (1975) and Wolfe et al. (1981) interpret both types as representing the same impact and attribute 
differences in texture to different cooling histories. These differences led Spudis et al. (1981) to conclude that these distinctive breccia types probably did not originate from the same impact. Hence, the Apollo 17 landing site may consist of ejecta from both local craters and larger distant craters, not solely ejecta from the Serenitatis basin (Spudis et al., 1981).

Due to the lack of distinctly identifiable stratigraphic relationships between different breccia types, radiometric age dating became a focus of studies subsequent to the sample delivery in an attempt to resolve the existing diversity of interpretations. A precise chronology of different breccia types can help to identify samples that are different in age and hence, cannot have formed by the same impact. Previous ${ }^{40} \mathrm{Ar} /{ }^{39} \mathrm{Ar}$ studies of breccia 76055 (sampled close to Station 6 at the North Massif) produced plateau ages of 3.91 $\pm 0.04 \mathrm{Ga}$ (Huneke et al., 1973) and 3.92 $\pm 0.05 \mathrm{Ga}$ (Turner et al., 1973), which were interpreted to be the time of the Serenitatis impact event. Cadogan et al. (1976) obtained ${ }^{40} \mathrm{Ar} /{ }^{39} \mathrm{Ar}$ ages for 15 samples of clasts, matrix and mineral concentrates (North Massif, Station 6 boulder) ranging from $3.86 \pm 0.04 \mathrm{Ga}$ to $4.04 \pm 0.05 \mathrm{Ga}$ and argued that the age of the Serenitatis impact is $3.90 \pm 0.04$ $\mathrm{Ga}$, although this age range was also thought to be a reflection of the amount of degassing (Schaeffer et al., 1977). Jessberger et al. (1977) suggested an age of 3.88 $\pm 0.03 \mathrm{Ga}$ for the Serenitatis impact based on ${ }^{39} \mathrm{Ar} /{ }^{40} \mathrm{Ar}$ dating on one aphanitic matrix breccia (73255) sampled at the South Massif.

The observed scatter in ${ }^{40} \mathrm{Ar} /{ }^{39} \mathrm{Ar}$ ages resulted in uncertainty in the interpretation of the breccias and the suggested timing of the Serenitatis impact. Nakamura et al. (1976) assigned the age of $3.9 \mathrm{Ga}$ to the Serenitatis impact event, while Wilhelms et al. (1987) argued that the age of the Serenitatis impact is $3.86-3.87 \mathrm{Ga}$ based on the youngest ${ }^{39} \mathrm{Ar} /{ }^{40} \mathrm{Ar}$ age for sample 73255 (Huneke, 1978) and one single-crystal plagioclase clast from sample 72435 (Station 2, South Massif). Dalrymple et al. (1996) obtained ${ }^{40} \mathrm{Ar} /{ }^{39} \mathrm{Ar}$ age spectra by laser step heating on poikilitic and aphanitic breccias. Three of the poikilitic breccias (from the North and South Massif) yielded a weighted mean age of $3893 \pm 9 \mathrm{Ma}$, which was evaluated as the best estimate for the Serenitatis impact. However, the studied aphanitic samples (72255, Station 2, South Massif) have plateau ages ranging from $3867 \pm 16 \mathrm{Ma}$ to $3951 \pm 17 \mathrm{Ma}$, suggesting a complex and prolonged chronological history of the aphanitic breccias (Dalrymple et al., 1996). These ages indicate that the distinct breccias have different impact histories and that the aphanitic samples may in fact not originate from the Serenitatis impact event. However, the majority of the determined ${ }^{40} \mathrm{Ar} /{ }^{39} \mathrm{Ar}$ ages were calculated with the old decay constants and monitor ages, which leads to additional inconsistency and a spread of ages when compared to more recent ${ }^{40} \mathrm{Ar} /{ }^{39} \mathrm{Ar}$ ages. 
The present study focusses on the U-Pb system in phosphates in an attempt to shed additional light on the question whether the Apollo 17 impact melt breccias were formed in a single impact, e.g. the Serenitatis impact, or whether different textual types represent distinctive impact events. To distinguish between these hypotheses, ${ }^{207} \mathrm{~Pb} /{ }^{206} \mathrm{~Pb}$ ages of phosphate grains from the texturally different impact breccia types sampled at the North and South Massifs were determined by Secondary Ion Mass Spectrometry (SIMS). The advantage of SIMS analyses is that single grains can be dated in situ and thus, the possibility of measuring unrelated mineral mixtures is reduced and a large number of individual data points can be acquired that define a statistically significant population. Phosphates provide an opportunity for determining impact ages because of their relatively low closure temperatures around 450$550{ }^{\circ} \mathrm{C}$ (e.g. Cherniak et al., 1991) when compared to zircon, based on cooling rates of $10^{\circ} \mathrm{C} / \mathrm{Ma}$ and $1^{\circ} \mathrm{C} / \mathrm{Ma}$ and grain radii smaller than $0.5 \mathrm{~mm}$. Hence, the U-Pb system of phosphates is prone to resetting during an impact event (Nemchin et al., 2009; Abramov et al., 2009) and the U-Pb age in phosphates is expected to reflect that of the time of the breccia formation.

\section{Geology of the Taurus-Littrow Valley}

The Taurus-Littrow area is mainly a highland region close to the intersection of Mare Serenitatis and Mare Tranquillitatis. Originally, Serenitatis had been interpreted as one of the oldest basins on the Moon, occurring during the Pre-Nectarian period (e.g. Stuart-Alexander et al., 1970; Hartmann et al., 1971). Subsequent studies have suggested that it is younger (Nectarian in age), mainly due to the relatively young ages of the Apollo 17 samples, interpreted as Serenitatis ejecta (e.g. Dalrymple et al., 1996), but also based on stratigraphic observations such as secondary craters, which are interpreted as originating from the Serenitatis impact event, superposed on Crisium basin material (e.g. Wilhelms et al., 1987). Nevertheless, analyses of more recent high resolution imagery concluded that Serenitatis is indeed a relatively old Pre-Nectarian basin (Spudis et al., 2011; Fassett et al, 2012).

Wilhelms et al. (1971) mapped the Serenitatis basin as consisting of four rings, with the Apollo 17 landing site positioned between the second and third ring. The Taurus-Littrow valley is interpreted as a deep graben, which is thought to have formed during the Serenitatis impact event (Muehlberger et al., 1973). The highland region is mainly comprised of breccias, most of which are thought to originate from the Serenitatis impact covered by younger ejecta from distant basins (Scott et al., 1972). The area can be divided into (1) high massifs, (2) so- 
called Sculptured Hills, and (3) low hills. The massifs cluster around the Apollo 17 landing site and are interpreted to have been uplifted by the Serenitatis impact, and possibly exposing ejecta from older basins (e.g. Tranquillitatis; Head, 1974a). The Sculptured Hills comprise a group of closely-spaced highland hills located between the Serenitatis and Crisium basins. Since the Sculptured Hills resemble the Alpes Formation of the Imbrium basin, Head (1974a) interpreted them as equivalent features generated by the Serenitatis impact. The Apollo 17 highland samples were collected at the massifs close to the Sculptured Hills and were, therefore, also interpreted as being related to the Serenitatis impact (Head 1974a). These samples may consist of fragments of massif material (i.e. originating from older impact basins) or pieces of the Serenitatis impact melt sheet (Warner et al., 1976; Winzer et al., 1977). However, at the time of this interpretation, the morphological differences between the massifs and the Sculptured Hills were not clearly understood (Muehlberger et al., 1973). Spudis et al. (2011) investigated new Lunar Reconnaissance Orbiter Camera (LROC) images, which do not support the previous interpretation of the Sculptured Hills being related to the Serenitatis impact event. The analyzed Wide-Angle Camera (WAC) images show that the Sculptured Hills are not only concentrated around the Apollo 17 landing site, but that they occur widespread within the Taurus Mountains. Moreover, the images reveal that the Sculptured Hills superpose the rims of post-Serenitatis craters such as Le Monnier and Littrow (Spudis et al., 2011). This observation confirms the previous findings from Spudis et al. (1981), who argued that the Sculptured Hills cannot originate from the Serenitatis impact if they overlie stratigraphic younger post-Serenitatis impact basins.

The samples analyzed in the present study were collected from boulders at Station 2 at the South Massif (72255) and near or from boulders at Station 6 at the North Massif (76015, 76215 and 76055) as indicated in Figure 1. These boulders are interpreted to have rolled down the slopes of the massifs to their present locations (Muehlberger et al., 1973). In the case of the North Massif, the boulders are thought to originate from one larger boulder that broke into several pieces. Samples collected at the South Massif probably came from an area near the top of the massif, whereas breccias sampled at the North Massif were likely derived from within the lower third of the North Massif (Muehlberger et al., 1973). This stratigraphic setting suggests that the boulders represent different stratigraphic units. However, the lithologies of the boulders are rather similar and therefore, may also represent a single stratigraphic unit.

The analyzed samples, which can be divided into micropoikilitic (76015 and 76215), aphanitic (72255) and subophitic-micropoikilitic (76055) impact melt breccias are described in detail in the following section (Fig. 2). 


\section{Sample description}

Thin sections 72255,99; 72255,125; 72255,306

170 Sample 72255 (2461 g) was collected from the side of boulder 1 at Station 2 on the bottom 171 slope of the South Massif. The boulder consisted of several layers with clasts that weathered 172 out as knobs and sample 72255 is one of these knobs (e.g. Ryder et al. 1975a). The sample 173 has a layered gray aphanitic matrix and is comprised of several dark grey clasts (Simonds et al., 1974). The matrix is fine-grained and heterogeneous and the crystalline melt groundmass consists of plagioclase, pyroxene, ilmenite and metallic iron (Ryder, 1993). The aphanitic breccia has a trace element pattern enriched in KREEP elements (K, REE, and P; Palme et al., 1978; Warren et al., 1979) and it is the only sample containing zircon among all the studied breccias. Phosphates in the investigated thin sections have an average size of 35 x $50 \mu \mathrm{m}$, although one grain measures $40 \times 75 \mu \mathrm{m}$. Most of the phosphate grains occur as fragments, are embedded within the matrix and are subhedral in shape (Fig. 2a). Some of the boundaries to adjacent grains are straight, while other grains show rounded or embayed boundaries. However, some of the grains occur in voids and are attached to adjacent grains. Several different radiometric ages were derived previously for this breccia. $\mathrm{A}{ }^{40} \mathrm{Ar} /{ }^{39} \mathrm{Ar}$ age of 4.01 $\pm 0.03 \mathrm{Ga}$ was obtained by Leich et al. (1975) for the matrix, whereas Dalrymple et al. (1996) determined several ${ }^{40} \mathrm{Ar} /{ }^{39} \mathrm{Ar}$ plateau ages for different clasts, ranging from $3.835 \pm 0.016 \mathrm{Ga}$ for the poikilitic melt clast to $>3.894 \mathrm{Ga}$ for two aphanitic "blobs". However, the weighted average age of $3.893 \pm 0.009 \mathrm{Ga}$ was interpreted to be the age of the Serenitatis impact (Dalrymple et al., 1996).

\section{Thin sections 76055,74}

Sample 76055 (6412 g) was collected 10-15 m away from the large boulder at Station 6. It was classified as a micropoikilitic-subophitic breccia by Simonds et al. (1974) and it appears to be compositionally distinct from the Station 6 boulder (Wolfe et al., 1981). Moreover, it exhibits a prominent foliation which is defined by many small lenticular vesicles. Sample 76055 can be further divided into three lithologies: vesicular, non-vesicular and an unstudied dense region (Meyer, 2008). In general, it exhibits a fine-grained vesicular groundmass and contains about $41 \%$ plagioclase, $24 \%$ low-Ca pyroxene, $18 \%$ olivine and minor augite, armalcolite and iron metal (Albee et al., 1973). The phosphates occur in voids as euhedral to 
subhedral grains. Their average size is $25 \times 30 \mu \mathrm{m}$, with the largest grain measuring $75 \times 90$ $\mu \mathrm{m}$. They often occur together with metallic iron (Fig. 2b). The 76055 breccia has yielded ${ }^{40} \mathrm{Ar} /{ }^{39} \mathrm{Ar}$ plateau ages of $3.98 \pm 0.05 \mathrm{Ga}$ to3.97 \pm 0.04 Ga (Turner et al., 1973; Huneke et al., 1973).

\section{Thin sections 76015,9; 76015,98}

Sample 76015 (2819 g) is a micropoikilitic breccia, which was sampled from Block 5 of the big boulder at Station 6 at the North Massif. The color and texture is similar to sample 76215 . It consists of about 50\% feldspar, $40 \%$ low-Ca pyroxene, 5\% augite and minor amounts of olivine, ilmenite, metallic iron, spinel and phosphates (e.g. Phinney, 1981). The matrix is primarily composed of a dense network of elongated low-Ca pyroxene oikocrysts, with tabular feldspar found both within and between the pyroxene grains (Ryder, 1993). The matrix is very vesicular with $<0.1 \mathrm{~mm}$ to $5 \mathrm{~cm}$ long irregular voids (Ryder, 1993). As with the subophitic breccia (76055), the majority of phosphates found in this sample occur within voids (Fig. 2c) and are attached to adjacent minerals. They are typically around $50 \mu \mathrm{m}$ in length, but the largest grain identified measures $75 \times 155 \mu \mathrm{m}$. The phosphate grains are euhedral to subhedral and some of the grains are fractured. $\mathrm{A}^{40} \mathrm{Ar} /{ }^{39} \mathrm{Ar}$ plateau age of $3.93 \mathrm{Ga}$ for the matrix was reported by Cadogan et al. (1976).

\section{Thin sections 76215,10; 76215,57; 76215,61}

Breccia 76215 (644 g) was sampled next to the large boulder at Station 6 at the North Massif, but it was most probably spalled from the top of block 4. It is a vesicular, crystalline matrix breccia and has a poikilitic texture, but some areas exhibit an ophitic texture. It consists of about $50 \%$ plagioclase, $15-30 \%$ pyroxene, $5-11 \%$ augite, about $7 \%$ olivine, $2 \%$ ilmenite and minor amounts of olivine, metallic iron, spinel and phosphates (Simonds et al., 1974; Simonds, 1975). A majority of phosphate grains grew within vesicles and have a euhedral to subhedral shape. The grains are fractured and they usually show straight boundaries to adjacent minerals. Their average length of $70 \mu \mathrm{m}$ makes them the largest phosphates found in all analyzed samples. The largest grains in the sections have a length of $\sim 100-130 \mu \mathrm{m}$ (Fig. 2d). Previous radiometric age dating obtained a ${ }^{40} \mathrm{Ar} /{ }^{39} \mathrm{Ar}$ plateau age of $3.94 \pm 0.04 \mathrm{Ga}$ (Cadogan et al., 1976). 


\section{Analytical Techniques}

232

233

The thin sections were cleaned using an ultrasonic bath with distilled water and ethanol for the purpose of removing surface contamination. The sections were then carbon coated in order to facilitate initial scanning electron microscopy (SEM) analyses of the samples, including the acquisition of backscattered electron (BSE) images and element maps, which were used to determine the locations of the phosphate grains and investigate the textures of the samples. The SEM analyses were performed with a Quanta 650 FEGSEM and accompanying Oxford Instruments energy dispersive spectroscopy (EDS) detector at Stockholm University, using a $20 \mathrm{kV}$ accelerating voltage and $10 \mathrm{~mm}$ working distance. The same SEM settings were used to analyze the chemical composition of the phosphates and to distinguish between merrillite and apatite grains.

The sections were then cleaned a second time and coated with gold prior to performing the SIMS analyses. U-Pb isotopic data was collected using CAMECA 1280 ion microprobe at the NordSIMS facility, Swedish Museum of Natural History, Stockholm. The SIMS methodology closely followed the analytical description published elsewhere for zircon (e.g. Whitehouse et al., 1999; Whitehouse et al., 2005) and apatite (Nemchin et al., 2009; Snape et al., 2016). As a $\mathrm{U}-\mathrm{Pb}$ calibration reference for all analytical sessions the $2058 \mathrm{Ma}$ apatite crystal BRA-1 was used, with $67 \mathrm{ppm}$ of $\mathrm{U}$ and ${ }^{206} \mathrm{~Pb} /{ }^{204} \mathrm{~Pb}$ of 500 (Grange et al., 2009).

The mass filtered ${ }^{16} \mathrm{O}_{2}{ }^{-}$primary ion beam, with intensities between 1.7 and $5.3 \mathrm{nA}$, was defined by projection through Köhler apertures of $100 \mu \mathrm{m}, 150 \mu \mathrm{m}$ and $200 \mu \mathrm{m}$ in order to obtain spot sizes of $10 \mu \mathrm{m}, 15 \mu \mathrm{m}$ and $20 \mu \mathrm{m}$, respectively. Before each analysis, an area of 15-20 $\mu \mathrm{m}$ was pre-sputtered for 80 seconds in order to remove the gold coating from the area around the analytical spot and further limit the effects of sample contamination. Presputtering was followed by automatic centering of the secondary ion beam in the $4000 \mu \mathrm{m}$ field aperture and centering of the magnetic field. The secondary ions were measured using a "peak-hopping" routine with a single low-noise ion counting electron multiplier. The mass spectrometer was operated at a mass resolution of $5400(\mathrm{M} / \Delta \mathrm{M})$, sufficient to separate $\mathrm{Pb}$ peaks from molecular interferences.

Reduction of the SIMS data was performed using in-house developed software at NordSIMS for the CAMECA 1280 analyses and the Excel add-in Isoplot (version 4.15; Ludwig, 2008). In order to correct the data for the effects of contamination from terrestrial common $\mathrm{Pb}$ (most likely from the sample preparation, Nemchin et al., 2009) the model of Stacey et al. (1975) and their values for present-day terrestrial $\mathrm{Pb}$ isotopic ratios was used. The calculation of $\mathrm{U}$ - 
$\mathrm{Pb}$ ratios of the samples by SIMS requires a correction for matrix effects using independently characterized reference materials such as BRA-1. Additional uncertainties can be associated with minor differences in mineral chemistry, instrumental conditions during the analysis of standards and unknown samples and possible surface relief artefacts, particularly for grains located in voids. Consequently, the ${ }^{207} \mathrm{~Pb} /{ }^{206} \mathrm{~Pb}$ ratios are considered to give the best estimate of the sample ages. Additionally, several phosphates grains show reverse discordance making the calculation of Concordia ages impossible, and the $\mathrm{U}-\mathrm{Pb}$ intercept ages can be inaccurate if the reverse discordance is, as suspected, an analytical artefact of small matrix variations and/or surface imperfections. Thus, we primarily focus on ${ }^{207} \mathrm{~Pb} /{ }^{206} \mathrm{~Pb}$ ages in the following sections.

The obtained average ages discussed in the following sections were calculated with Isoplot at the $95 \%$ confidence limit, and individual analyses are shown in the plots with $2 \sigma$ errors. Following SIMS analyses, further SEM images of the analyzed phosphate grains were acquired in order to determine the exact location of SIMS spots and identify and exclude any likely sources of error in the measurements (e.g. whether the SIMS spots hit fractures or grain boundaries).

\section{Results}

The analyzed phosphates most likely originated from different source rocks (i.e. fragments vs. crystallization from the impact melt). However, in the simplest scenario their ${ }^{207} \mathrm{~Pb} /{ }^{206} \mathrm{~Pb}$ ages are assumed to reflect the time of the breccia formation. This assumption is based on the low closure temperatures of the U-Pb system in phosphates around $450-550{ }^{\circ} \mathrm{C}$, which should result in significant $\mathrm{Pb}$ mobility during an impact event and complete $\mathrm{Pb}$ loss. If the assumption of complete $\mathrm{Pb}$ loss is true, the small ${ }^{207} \mathrm{~Pb} /{ }^{206} \mathrm{~Pb}$ age differences between individual grains reflect the expected analytical scatter and a mean of all grains can be used to calculate average ages for each breccia. The weighted average ages calculated using Isoplot (Ludwig, 2008) include the calculation of a MSWD and probability of fit (P), providing an internal test of this assumption. A probability of fit $\geq 0.05$ indicates that the analyses represent a homogeneous population within the uncertainties. The ${ }^{207} \mathrm{~Pb} /{ }^{206} \mathrm{~Pb}$ ages obtained in three investigated samples form statistically valid age populations suggesting that the U-Pb system of the phosphates was completely reset by the impact that produced the breccias. five grains were merrillites and 36 grains were apatites. Merrillites occur only in the aphanitic 
and subophitic breccias. The apatite grains in the micropoikilitic breccias are larger (average lengths around 50-70 $\mu \mathrm{m}$ ) than the merrillite and apatite grains found in the aphanitic and subophitic breccias (average lengths around 30-35 $\mu \mathrm{m}$ ). The results are summarized in Table 1.

\section{Sample 72255 (aphanitic)}

A total of six analyses were made on five individual phosphate grains (two merrillites, three apatites) in three thin sections. These phosphates yielded an average ${ }^{207} \mathrm{~Pb} /{ }^{206} \mathrm{~Pb}$ age of $3922 \pm 5 \mathrm{Ma}(\mathrm{MSWD}=0.79, \mathrm{P}=0.56$ ). As indicated by the low MSWD, all of the individual ${ }^{207} \mathrm{~Pb} /{ }^{206} \mathrm{~Pb}$ ages for each analyzed grain match within the error, regardless whether the grains occur as fragments or within voids.

\section{Sample 76055 (subophitic-micropoikilitic)}

In this sample 22 analyses on twelve grains (three merrillites, nine apatites) were made, leading to an average ${ }^{207} \mathrm{~Pb} /{ }^{206} \mathrm{~Pb}$ age of $3920 \pm 3 \mathrm{Ma}(\mathrm{MSWD}=0.71, \mathrm{P}=0.83$ ). The individual ${ }^{207} \mathrm{~Pb} /{ }^{206} \mathrm{~Pb}$ ages range from $3911 \pm 20 \mathrm{Ma}$ to $3940 \pm 23 \mathrm{Ma}$ and are, therefore, indistinguishable within the error of each other.

\section{Sample 76015 (micropoikilitic)}

In the two 76015 thin sections 15 analyses of eleven apatite grains were made. An average ${ }^{207} \mathrm{~Pb} /{ }^{206} \mathrm{~Pb}$ age of $3930 \pm 7 \mathrm{Ma}(\mathrm{MSWD}=1.3, \mathrm{P}=0.17)$ was derived. The youngest ${ }^{207} \mathrm{~Pb} /{ }^{206} \mathrm{~Pb}$ age obtained is $3906 \pm 50 \mathrm{Ma}$, whereas the oldest ${ }^{207} \mathrm{~Pb} /{ }^{206} \mathrm{~Pb}$ age is $3952 \pm 40 \mathrm{Ma}$.

\section{Sample 76215 (micropoikilitic)}

In total 31 analyses on 13 apatite grains were obtained in the three thin sections from sample 76215. The grains have an average size of $50 \times 70 \mu \mathrm{m}$ and therefore, several analyses could be performed in single phosphate grains. Grain \#47 is one of the largest (95x $115 \mu \mathrm{m}$, Fig. 2d) and exhibits the largest spread of ${ }^{207} \mathrm{~Pb} /{ }^{206} \mathrm{~Pb}$ ages, ranging from $3904 \pm 72 \mathrm{Ma}$ at the rim of the grain to $4051 \pm 87 \mathrm{Ma}$ in the center of the grain. It is possible that this large and relatively unfractured grain represents a rare case of incomplete resetting of the $\mathrm{U}-\mathrm{Pb}$ system. The 
weighted average ${ }^{207} \mathrm{~Pb} /{ }^{206} \mathrm{~Pb}$ age of $3957 \pm 41 \mathrm{Ma}$ for this grain however, overlaps within the error with the average age of the whole sample, and the statistical fit for individual spots within this grain is considered valid $(\mathrm{MSWD}=2.6, \mathrm{P}=0.053)$. While the determined age of $4051 \pm 87 \mathrm{Ma}$ is a unique observation within all the samples, it is hard to tell from a single measurement whether this old age might represent an (unlikely) analytical artefact or whether it reflects a real age. Consequently, this older age was excluded in the average ${ }^{207} \mathrm{~Pb} /{ }^{206} \mathrm{~Pb}$ age of $3931 \pm 7 \mathrm{Ma}(\mathrm{MSWD}=2.7, \mathrm{p}=0$ ) yielded for this sample. Although a high MSWD and low probability indicates scatter in excess of the analytical uncertainties, this age is taken as the best estimate of the time of the breccia formation.

\section{Discussion}

\subsection{Textural and chemical variability of the Apollo 17 breccias}

Relating breccias to specific impact basins is complicated by: 1) the acquisition of samples from the lunar regolith rather than genuine outcrops of bedrock; and 2) a lack of information linking stratigraphic units and specific impacts on the Moon. Nevertheless, in the case of the Apollo 17 samples, the chemical and textural differences between the aphanitic and poikilitic breccias have led to the conclusion that they may represent different impacts (e.g. Spudis et al., 1981). The aphanitic breccias, as a group, show a large range of chemical compositions, but the individual samples are all different from the poikilitic breccias (Spudis et al., 1981). The aphanitic breccia 72255 sampled at the South Massif has a higher $\mathrm{Al}_{2} \mathrm{O}_{3}$ content $(\sim 21 \%)$ than the micropoikilitic breccias $(76015,76215)$ sampled at the North Massif ( 18\% ; Simonds, 1975; Wolfe, 1975). Moreover, the $\mathrm{MgO}(11 \%), \mathrm{TiO}_{2}(0.8 \%)$ and $\mathrm{FeO}(\sim 8.45 \%)$ concentrations of the aphanitic breccia are slightly lower when compared to the poikilitic breccias $\left(\mathrm{MgO} \sim 12.5 \%, \mathrm{TiO}_{2} \sim 1.5 \%\right.$ and $\mathrm{FeO} \sim 8.8 \%$; Simonds, 1975; Wolfe, 1975). The U and Th concentrations of breccia 72255 ( $\mathrm{U} \sim 1.41 \mathrm{ppm}$ and $\mathrm{Th} \sim 4.3-5.8 \mathrm{ppm}$ ) and breccias 76015 and 76215 ( $\mathrm{U} \sim 1.2-1.96 \mathrm{ppm}$ and $\mathrm{Th} \sim 4.18-5.56 \mathrm{ppm}$ ) are the same within uncertainty. However, the majority of rare earth element (REE) abundances are slightly higher in the micropoikilitic breccias when compared to the aphanitic breccias (e.g. Palme et al., 1978; Simonds, 1975 and references within). The micropoikilitic breccias exhibit the highest $\mathrm{Zr}$ abundances (480 ppm; Palme et al., 1978), but zircon grains occur only within the aphanitic breccia 72255 ( $\mathrm{Zr}$ concentration of $400 \mathrm{ppm}$ ). This indicates that either the target of the impact that produced breccia 72255 contained evolved KREEP-rich rocks or that these rocks were mixed into the ejecta during its deposition at the South Massif at the Apollo 17 
landing site, since only KREEP-rich magma has adequate $\mathrm{Zr}$ concentrations for zircon to crystallize (Dickinson et al., 1982). The subophitic breccia (76055) is chemically distinct from all the other breccias collected at the Apollo 17 landing site. It exhibits higher $\mathrm{MgO}$ concentrations of $\sim 16.5 \%$, lower $\mathrm{Al}_{2} \mathrm{O}_{3}$ concentrations of $\sim 16 \%$ and has slightly lower $\mathrm{U}$ (0.88 ppm) and Th (3.52 ppm) abundances (Palme et al., 1978) compared to the aphanitic and micropoikilitic breccias, and the REE concentrations are the lowest among the four analyzed breccias (Palme et al., 1978). These chemical and textural differences indicate different melt compositions and cooling histories, which either requires distinct impact events or at least significant differences in target composition.

The majority of phosphates occurring within the aphanitic and subophitic breccias have higher $U$ contents $(50-270 \mathrm{ppm})$ than the average $U$ concentrations of phosphates found within the micropoikilitic breccias ( $U<70$ ppm; Fig. 3), but there is no observed difference between merrillite and apatite grains. However, the five merrillite grains exhibit much higher Th concentrations $(\sim 560-2070 \mathrm{ppm})$ than the apatites $(\sim 5-550 \mathrm{ppm})$. The Th content of apatites in the aphanitic and two micropoikilitic breccias is similar but apatite grains found within the subophitic breccia have the lowest Th values (<80 ppm). Overall, the Th and U concentrations observed in the apatites and merrillites investigated in the four samples suggest that phosphates in the three textural types of breccias have crystallized in three chemically different source rocks.

Additional information about the origin of the breccias can be obtained by comparing their highly siderophile elements (HSE) signature. The HSE concentrations are directly linked to the impactors that produced the impact melts since the melts incorporate exogenic materials from the impactors, which are typically enriched in HSE compared to endogenic planetary crusts (Liu et al., 2012). Morgan et al. (1974) analyzed 17 elements from several impact melt breccias, including the HSE $\mathrm{Au}$, Ir and Re, from all Apollo landing sites and divided them into six groups based on their Ir, Au and Ge proportions. Two different HSE signatures referred to as Group 2 and Group 3 were observed in the aphanitic (Group 3) and micropoikilitic (Group 2) breccias sampled at the Apollo 17 landing site (Morgan et al., 1974; Hertogen et al., 1977). The Group 2 signature is representative of enstatite chondrites and the Group 3 signature is similar to ordinary chondrites based on the HSE relationships (Gros et al., 1976). However, a subsequent study by Sharp et al. (2014) suggested that all Apollo 17 melt rocks originated from the same impactor which had a HSE signature that is not represented in the studied terrestrial meteorite collection, or that the observed HSE signatures 
breccia 76055 exhibit an anomalous HSE signature according to Sharp et al. (2014) and therefore, it is thought to have formed by an impact other than the one that produced the aphanitic and poikilitic breccias. Regardless of the precise interpretation of the HSE behavior in the investigated Apollo 17 breccias, their distribution appears to support the possibility of several impacts being responsible for the formation of these samples.

Taking the distinctive chemical compositions of the textually different breccias into account together with their different HSE signatures, the simplest interpretation is that the breccias are the products of three different impact events. If they were formed by a single impact, the observed differences would require either a very heterogeneous target and absence of mixing within the ejecta during its transportation or addition of various proportions of older material of different origin and composition into the ejecta during its deposition at the Apollo 17 landing site.

\subsection{Ages of the Apollo 17 breccias}

6.2.1 The possibility of three distinct impact events

Based on the obtained average ${ }^{207} \mathrm{~Pb} /{ }^{206} \mathrm{~Pb}$ ages, the subophitic breccia 76055 can be interpreted to have formed at $3920 \pm 3 \mathrm{Ma}$, the aphanitic breccia 72255 at $3922 \pm 5 \mathrm{Ma}$, and the micropoikilitic breccia 76015 at $3930 \pm 7$ Ma (Fig. 4). The only sample that shows scatter beyond the analytical uncertainties, and thus indicating the possibility of incomplete homogenization, is micropoikilitic breccia 76215 . However, its average ${ }^{207} \mathrm{~Pb} /{ }^{206} \mathrm{~Pb}$ age of $3931 \pm 7 \mathrm{Ma}$ is notably similar to that of the other micropoikilitic sample and an average ${ }^{207} \mathrm{~Pb} /{ }^{206} \mathrm{~Pb}$ age of $3930 \pm 5 \mathrm{Ma}(\mathrm{MSWD}=0.14, \mathrm{P}=0.71)$ can be obtained (Fig. 5). This observation suggests that this age may represent the true time of breccia formation. The excess scatter is a result of either slightly underestimated uncertainties of individual spot analyses or a small degree of post-formation disturbance, which is not possible to detect by

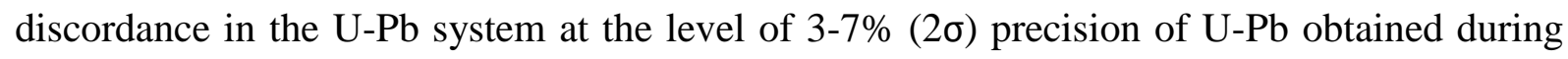
phosphate SIMS analysis. If this is correct, the ${ }^{207} \mathrm{~Pb} /{ }^{206} \mathrm{~Pb}$ age range of $\sim 11 \mathrm{Ma}$ between the two micropoikilitic breccia samples and the subophitic and aphanitic breccias is in excess of the analytical errors and has to represent a real difference in their formation time. The ${ }^{207} \mathrm{~Pb} /{ }^{206} \mathrm{~Pb}$ age of the subophitic breccia $(3920 \pm 3 \mathrm{Ma})$ is indistinguishable within error limits from the aphanitic breccia $(3922 \pm 5 \mathrm{Ma})$ and an average ${ }^{207} \mathrm{~Pb} /{ }^{206} \mathrm{~Pb}$ age of $3921 \pm 2 \mathrm{Ma}$ (MSWD $=0.92, \mathrm{P}=0.34)$ can be obtained. Even though these ages are indistinguishable within error, the two samples show different textures, distinct compositions, different HSE 
signatures and the subophitic breccia does not contain any zircon. These findings indicate that the samples are not derived from the same material and the similarity in age is probably coincidental.

These combined geochronological, textural and chemical observations indicate that the three different textural types of breccias have probably originated from at least three impact events, which occurred at 3920 $\pm 3 \mathrm{Ma}, 3922 \pm 5 \mathrm{Ma}$ and 3930 $\pm 5 \mathrm{Ma}$ (Fig. 5).

\subsubsection{Lunar initial $\mathrm{Pb}$ and/or the possibility of incomplete resetting}

The apparent difference in phosphate ages between different samples can also be interpreted as a result of incomplete $\mathrm{Pb}$ loss and/or the presence of minor amounts of lunar initial $\mathrm{Pb}$ unsupported by the in situ decay of $U$ following the breccia forming impact. The presence of unsupported $\mathrm{Pb}$ is, in principal, easy to detect if its proportion is relatively large, as it should also affect concordance of individual analyses. However, small fractions of unsupported $\mathrm{Pb}$ capable of changing the estimated ${ }^{207} \mathrm{~Pb} /{ }^{206} \mathrm{~Pb}$ ages by $10-15 \mathrm{Ma}$ are difficult to identify, particularly, because laboratory contamination is also present to various degrees in all analyzed samples. Consequently, the interpretation that the observed $11 \mathrm{Ma}$ difference in age between the micropoikilitic $(76015,76215)$ and the two younger breccias is due to the lower U concentrations in the phosphates from 76015 and 76215 and resulting larger proportion of unsupported $\mathrm{Pb}$ in the overall $\mathrm{Pb}$ balance cannot be discarded completely.

One available way to test for the small contribution of unsupported $\mathrm{Pb}$ is to plot the ${ }^{207} \mathrm{~Pb} /{ }^{206} \mathrm{~Pb}$ ratios against the ${ }^{204} \mathrm{~Pb} /{ }^{206} \mathrm{~Pb}$ ratios. The majority of the analyzed phosphate grains have very low ${ }^{204} \mathrm{~Pb} /{ }^{206} \mathrm{~Pb}$ ratios $(<0.0002)$ and thus, the initial $\mathrm{Pb}$ contamination is marginal. Only a minority of grains (mostly in thin section 76215,61 ) have ${ }^{204} \mathrm{~Pb} /{ }^{206} \mathrm{~Pb}$ ratios $>0.0002$, but no difference between older and younger grains is observed (i.e. there is no apparent relationship between the ${ }^{204} \mathrm{~Pb} /{ }^{206} \mathrm{~Pb}$ ratios and the ages of the grains). Figures $6 \mathrm{a}$ and $6 \mathrm{~b}$ show that the trend of all analyzed grains (prior to the correction for terrestrial common $\mathrm{Pb}$ ) points towards modern terrestrial $\mathrm{Pb}$ (Stacey et al., 1975), which implies that the samples were largely contaminated by common terrestrial $\mathrm{Pb}$ during sample cutting and polishing. With decreasing ${ }^{204} \mathrm{~Pb} /{ }^{206} \mathrm{~Pb}$ ratios the common terrestrial $\mathrm{Pb}$ contamination is decreasing and analyses with low ${ }^{204} \mathrm{~Pb} /{ }^{206} \mathrm{~Pb}$ ratios $(<0.0002)$ are expected to fall along a steeper trend pointing towards lunar initial $\mathrm{Pb}$, if residual quantities of this $\mathrm{Pb}$ are present in phosphate grains. When only these analyses with ${ }^{204} \mathrm{~Pb} /{ }^{206} \mathrm{~Pb}$ ratios $<0.0002$ are considered, they still fall along a shallow trend which is suggestive of common terrestrial $\mathrm{Pb}$ contamination (Fig. 6c). 
Thus, the age range of $\sim 11 \mathrm{Ma}$ between the micropoikilitic and the subophitic and aphanitic breccias still appears to reflect the true difference of their formation time.

The ${ }^{207} \mathrm{~Pb} /{ }^{206} \mathrm{~Pb}$ age of $3920 \pm 3 \mathrm{Ma}$ obtained from the subophitic breccia (76055) can be taken as the true time of an impact as this sample shows extremely low ${ }^{204} \mathrm{~Pb}$ concentrations and therefore, the influence of unsupported lunar initial $\mathrm{Pb}$ is also smaller than the $\pm 3 \mathrm{Ma}$ uncertainty determined for this sample. In addition, analyses of individual grains show a relatively narrow range of ${ }^{207} \mathrm{~Pb} /{ }^{206} \mathrm{~Pb}$ ages, even though the size of the grains varies from about 20 to $100 \mu \mathrm{m}$ in lengths and incomplete resetting of the U-Pb system would be expected to be more pronounced in the larger grains. Therefore, both inter- and intra-grain homogeneity of ${ }^{207} \mathrm{~Pb} /{ }^{206} \mathrm{~Pb}$ ages observed in this sample indicates complete resetting of the phosphates in 76055. The aphanitic breccia 72255 exhibits a comparable internal homogeneity of ${ }^{207} \mathrm{~Pb} /{ }^{206} \mathrm{~Pb}$ ages and relatively small phosphate sizes, which suggests that the average age determined for the breccia is also largely unaffected by either unsupported lunar initial $\mathrm{Pb}$ or incomplete resetting of the $\mathrm{U}-\mathrm{Pb}$ system.

In contrast, the micropoikilitic breccias contain on average larger phosphate grains and exhibit more scatter of ${ }^{207} \mathrm{~Pb} /{ }^{206} \mathrm{~Pb}$ ages and hence, these may record incomplete resetting and contain some memory of the pre-impact accumulation of radiogenic $\mathrm{Pb}$. However, a correlation between grain size and ${ }^{207} \mathrm{~Pb} /{ }^{206} \mathrm{~Pb}$ age is not clear, especially in 76215 . This sample is the only one investigated in this study with an inter-grain variability of ${ }^{207} \mathrm{~Pb} /{ }^{206} \mathrm{~Pb}$ ages exceeding analytical error and it also contains the largest analyzed phosphate grains. Nevertheless, breccia 76215 also contains several relatively small grains $(<40 \mu \mathrm{m})$ that show ${ }^{207} \mathrm{~Pb} /{ }^{206} \mathrm{~Pb}$ ages in excess of $3940 \mathrm{Ma}$ which apparently have not been completely reset. On the other hand several relatively large grains (80 to $100 \mu \mathrm{m}$ in length) in both poikilitic breccia samples yield ages at the younger end of the range, between about 3920 and 3930 Ma. This observation suggests that even if there is a small degree of incomplete resetting of the U$\mathrm{Pb}$ system in some of the phosphate grains from 76215 , it does not have a simple relation to the size of the grains. While the possibility of incomplete resetting cannot be fully dismissed, it also cannot be confirmed with an absolute certainty. Therefore, the $11 \mathrm{Ma}$ age difference between the micropoikilitic and other types of breccias remains a valid assumption. Additional data obtained using different dating techniques allowing similar level of precision, but exhibiting different resetting behavior (e.g. ${ }^{40} \mathrm{Ar} /{ }^{39} \mathrm{Ar}$ ), may help to resolve this ambiguity. 
A key assumption made here, with respect to the behavior of U-Pb systems in phosphate grains, is that although lunar breccias are likely to represent a complex mixture of different components, which may include local and foreign materials (e.g. material from different impact events in addition to the primary magmatic rocks sourced at the impacts' target; e.g. Petro et al., 2008; Gault et al., 1974), the Ca-phosphates are prone to $\mathrm{Pb}$ loss at relatively mild thermal disturbances. Consequently, temperatures attained during the formation of the studied breccia samples should have been sufficient to reset the U-Pb systems in the analyzed phosphates to the same age, defining formation time of these samples, even if the phosphate crystallization ages were very different prior to the breccia consolidation.

If this assumption is correct, the observed $11 \mathrm{Ma}$ difference in ages between the micropoikilitic and the aphanitic/subophitic breccias combined with the chemical and textural differences of the analyzed samples may indicate three distinct impact events. This creates a substantial problem for the traditional interpretation of the analyzed samples, which suggests Serenitatis and/or Imbrium as likely candidates for the origin of the Apollo 17 breccias. Importantly, the observed age difference also conflicts with the interpretation that all Apollo 17 breccias originate from the same impact (i.e. Serenitatis). Even if the older age of the poikilitic breccias is interpreted as an indication of incomplete resetting of the $\mathrm{U}-\mathrm{Pb}$ system, the age defined by the aphanitic and subophitic breccias is very similar to that defined for the Imbrium impact based on analysis of Ca-phosphates from Apollo 14 breccias (Snape et al. 2016), Apollo 12 impact melt breccias (Liu et al., 2012) and zircons from SaU169 (Gnos et al., 2004). Consequently, this interpretation would lead to the conclusion that none of Apollo 17 breccias represent Serenitatis impact ejecta.

Accepting a common interpretation that Apollo 17 poikilitic breccias originate from the Serenitatis impact, while the aphanitic breccias from the South Massif are Imbrium ejecta, the average ${ }^{207} \mathrm{~Pb} /{ }^{206} \mathrm{~Pb}$ age of $3930 \pm 5 \mathrm{Ma}$ obtained for the micropoikilitic breccias $(76215$, 76015) might be viewed as the best estimate of the Serenitatis impact and the aphanitic breccia (72255) age of $3922 \pm 5 \mathrm{Ma}$ as defining the age of the Imbrium impact. This interpretation appears to be in agreement with the suggestion that the poikilitic breccias were derived from a boulder which is stratigraphically older than the source boulder of the aphanitic breccias (Muehlberger et al., 1973). However, this interpretation of breccia ages also means that about 13 to 25 basins formed within an extremely narrow time interval of a few million years between the Serenitatis and Imbrium impacts, especially if Serenitatis is indeed a relatively old Pre-Nectarian basin (Spudis et al., 2011; Fassett et al., 2012). While the aphanitic breccia (72255) with the age of $3922 \pm 5$ Ma may not originate from the Imbrium 
impact, but rather from a smaller crater of similar age, the issue with short period of time

528 between Imbrium and Serenitatis still exists as long as the poikilitic breccias are viewed as Serenitatis ejecta and the Apollo 14 breccias are interpreted as deposits from the Imbrium impact. Taking the apparent conflict between the U-Pb phosphate data and stratigraphic interpretation of investigated breccias into account, a comprehensive search for possible alternative sources for the breccias is warranted and has to consider all Nectarian and PreNectarian impact basins/craters that have continuous ejecta blankets reaching the Apollo 17 landing site. Although not fully exhaustive and not accounting for all complexities in the ejecta propagation and deposition this can be done to a first order approximation using the following equation for the continuous ejecta radius:

$$
R_{c e}=(2.3 \pm 0.5) R^{1.006}
$$

where $R_{c e}$ is the radius of the continuous ejecta blanket (in kilometers) and $R$ is the radius of the impact crater (Moore et al., 1974; Melosh, 1989). This formula is only valid for craters with a diameter $<436 \mathrm{~km}$. It was nevertheless applied to impact craters ranging from $\sim 1 \mathrm{~km}$ up to $2500 \mathrm{~km}$ (South Pole Aitken) to get an approximate estimate of the ejecta distribution. Furthermore, the distance of the basins and craters to the North and South Massifs was estimated in order to assess if the continuous ejecta blankets reach the sample locations. In order to get an estimate of the thickness $(t)$ of ejecta deposits at the Apollo 17 landing site, two additional equations were used. The following equation was used for simple craters (diameter $<15 \mathrm{~km})$ :

$$
t=0.04 R(r / R)^{-3 \pm 0.5}
$$

where $r$ is the distance from the crater center to the Apollo 17 landing site (in meters; Kring, 1995). For complex craters (diameter $>15 \mathrm{~km}$ ) the following equation (McGetchin et al., 1973) was used:

$$
t=0.14 R^{0.74}(r / R)^{-3 \pm 0.5}
$$

Based on equation (1), six impact basins (Tranquillitatis, Fecunditatis, Crisium, Nectaris, Serenitatis and Imbrium, Fig. 7) would be expected to have continuous ejecta blankets at the North and South Massifs, and there are two large impact craters within the vicinity of the 
continuous ejecta deposit reaching Station 6 at the North Massif (Table A1). Moreover, based on equation (3) an ejecta thickness of $\sim 120 \mathrm{~m}$ from the South Pole-Aitken Basin impact event is expected to cover the Apollo 17 landing site. Material from the South Pole-Aitken basin as well as from the Tranquillitatis and Fecunditatis impact events might have been incorporated into the analyzed breccias during the last impact event that formed the breccias, but based on the ${ }^{207} \mathrm{~Pb} /{ }^{206} \mathrm{~Pb}$ ages these relatively old Pre-Nectarian basins can be excluded from the further consideration as sources for the breccias, for the same reason that was used to question the Serenitatis origin of the samples, i.e. formation of large number of basins in a short period of time of about $11 \mathrm{Ma}$.

A similar issue exists with two possible alternative sources of the breccias, Crisium ( 3.89 $\pm 0.02 \mathrm{Ga}$, Stöffler et al., 2001) and Nectaris ( 3.92 $\pm 0.03 \mathrm{Ga}$, Ryder et al., 1987). Based on equation (3) the average ejecta thickness of Nectaris and Crisium at the Apollo 17 landing site is estimated to be $\sim 120 \mathrm{~m}$ and $\sim 180 \mathrm{~m}$, respectively (McGetchin et al., 1973) and they can be viewed as potential candidates for the source of the breccia samples. If the micropoikilitic breccias indeed originated from the Nectaris impact and the aphanitic breccias from the Imbrium impact, then twelve basins formed within a short interval between $3922 \pm 5$ and $3930 \pm 5 \mathrm{Ma}$. In the case of Crisium, the predicted frequency of basin forming events is lower (four to five basins), according to the relative timing proposed by Fassett et al. (2012), Spudis et al. (2011), and Stöffler et al. (2006). In any case, if the ${ }^{207} \mathrm{~Pb} /{ }^{206} \mathrm{~Pb}$ age of $3922 \pm 5 \mathrm{Ma}$ is taken as the time of the Imbrium impact, then previous age estimates for Crisium defined as $3.89 \mathrm{Ga}$ (Stöffler et al., 2001) and the only radiometric age $\left({ }^{40} \mathrm{Ar} /{ }^{39} \mathrm{Ar}\right)$ of $3895 \pm 17 \mathrm{Ma}$ linked to the Crisium impact (Swindle et al., 1991) based on a few particles from the Luna 20 regolith, contradict the established stratigraphy. The crater "Henry" can also be excluded as it is superimposed on the $\sim 3.8 \mathrm{Ga}$ (Muehlberger et al., 1973) subfloor basalts covering the Apollo 17 landing site. It is a relatively young (Copernican) and small (diameter $\sim 700 \mathrm{~m}$ ) crater, not large enough to have excavated material from underneath the 1.0-1.4 km (Wolfe et al., 1981) thick basalt layer. An alternative possibility that has to be considered is that some or even all of these breccia samples could have been formed by impacts that are now covered by the extensive basaltic flows within the Serenitatis and/or Tranquillitatis basins. Table 2 provides a summary containing all the individual ${ }^{207} \mathrm{~Pb} /{ }^{206} \mathrm{~Pb}$ ages, textural descriptions and possible origins of the distinctive breccias. 
Combined with textural information, the ages obtained in this study potentially define three impact events within the textually distinct Apollo 17 samples: (1) around $3920 \mathrm{Ma}$ (subophitic breccia, 76055), (2) $3922 \mathrm{Ma}$ (aphanitic breccia, 72255), and (3) around $3930 \mathrm{Ma}$ (micropoikilitic breccias, 76015 and 76215). We consider Nectaris, Crisium or Serenitatis as the most likely sources for the micropoikilitic breccias. If we accept the traditional view that the micropoikilitic breccias were derived from the Serenitatis impact, we speculate that the ${ }^{207} \mathrm{~Pb} /{ }^{206} \mathrm{~Pb}$ age of $3930 \pm 5 \mathrm{Ma}$ is the age of Serenitatis impact event, while the aphanitic and subophitic breccias were formed by post-Serenitatis impacts. Whether the aphanitic breccia was excavated during the Imbrium impact or whether it represents different ejecta layers that were accumulated and mixed locally during an impact at $3922 \pm 5 \mathrm{Ma}$ is uncertain. The origin of the subophitic breccia remains unclear, especially based on the indistinguishable ${ }^{207} \mathrm{~Pb} /{ }^{206} \mathrm{~Pb}$ ages of the subophitic and aphanitic breccias. However, due to the differences in chemistry, texture and HSE signatures, we interpret this breccia as being composed of materials that are unrelated to the other breccias sampled in this study. Regardless of our interpretation, it is clear that further studies are necessary to identify the link between sampled breccias and impact basins.

\section{Acknowledgements}

We would like to thank the astronauts of the Apollo 17 mission for risking their lives in order to collect the samples and NASA for providing the samples. We would also like to thank Barbara Cohen and one anonymous reviewer for helpful comments which improved the manuscript. This work was funded by grants from the Knut and Alice Wallenberg Foundation and the Swedish Research Council to MJW and AAN. The NordSIMS facility is operated under a joint Nordic agreement; this is NordSIMS publication 482.

\section{References}

Abramov O. and Mojzsis S. J. 2009b. Simulations of diffusive $\mathrm{Pb}^{*}$-, Ti- and REE-loss in terrestrial and lunar zircon and apatite as a function of impact heating during impact bombardments (abstract \# 2040). AGU Fall Meeting Abstracts 1:2040.

Albee A. L., Gancarz A. J., and Chodos A. A. 1973. Metamorphism of Apollo 16 and 17 and Luna 20 metaclastic rocks at about 3.95 AE: Samples 61156, 64423, 14-2, 65015, 67483, 15-2, 76055, 22006, and 22007. Proceedings, 4th Lunar and Planetary Science Conference. pp. $569-595$. 
Cadogan P. H. and Turner G. 1976. The chronology of the Apollo 17 station 6 boulder. Proceedings, 7th Lunar and Planetary Science Conference. pp. 2267-2285.

Cherniak D. J., Lanford W. A., and Ryerson F. J. 1991. Lead diffusion in apatite and zircon using ion implantation and Rutherford Backscattering techniques. Geochimica et Cosmochimica Acta 5:1663-1673.

Dalrymple G. B. and Ryder G. 1996. Argon-40/argon-39 age spectra of Apollo 17 highlands breccia samples by laser step heating and the age of the Serenitatis basin. Journal of Geophysical Research 101:26069-26084.

Dickinson J. E. and Hess P. C. 1982. Zircon saturation in lunar basalts and granites. Earth and Planetary Science Letters 57:336-344.

Fassett C. I., Head J. W., Kadish S. J., Mazarico E., Neumann G. A., Smith D. E., and Zuber M. T. 2012. Lunar impact basins: Stratigraphy, sequence and ages from superposed impact crater populations measured from Lunar Orbiter Laser Altimeter (LOLA) data. Journal of Geophysical Research 117:2156-2202.

Gault D. E., Hörz F., Brownlee D. E., and Hartung J. B. 1974. Mixing of the lunar regolith. Proceedings, 5th Lunar and Planetary Science Conference. pp. 2365-2386.

Gnos E., Hofmann B. A., Al-Kathiri A., Lorenzetti S., Eugster O., Whitehouse M. J., Villa I. M., Jull A., J. T., Eikenberg J., Spettel B., Krähenbühl U., Franchi I. A., and Greenwood R.C. 2004. Pinpointing the source of a lunar meteorite: implications for the evolution of the Moon. Science 305:657-659.

Grange M. L., Nemchin A. A., Pidgeon R. T., Timms N., Muhling J. R., and Kennedy A. K. 2009. Thermal history recorded by the Apollo 17 impact melt breccia 73217. Geochimica et Cosmochimica Acta 73:3093-3107.

Gros J., Takahashi H., Hertogen J., Morgan J. W., and Anders, E. 1976. Composition of the projectiles that bombarded the lunar highlands. Proceedings, 7th Lunar and Planetary Science Conference. pp. 2403-2425.

Hartmann W. K. and Wood C. A. 1971. Moon: Origin and evolution of multi-ring basins. The Moon 3:3-78.

Head J. W. 1974a. Morphology and structure of the Taurus-Littrow highlands (Apollo 17): Evidence for their origin and evolution. The Moon 9:355-395.

Hertogen J., Janssens M. J., Takahashi H., Palme H., and Anders E. 1977. Lunar basins and craters-Evidence for systematic compositional changes of bombarding population. Proceedings, 8th Lunar and Planetary Science Conference. pp. 17-45.

Hinners N. W. 1973. Apollo 17 site selection. Apollo 17: Preliminary Science Report 330: 15.

Huneke J. C. 1978. ${ }^{40} \mathrm{Ar} /{ }^{39} \mathrm{Ar}$ microanalysis of single 74220 glass balls and 72435 breccia clasts. Proceedings, 9th Lunar and Planetary Science Conference. pp. 2345-2362.

Huneke J. C., Jessberger E. K., Podosek F. A., and Wasserburg G. J. $1973 .{ }^{40} \mathrm{Ar} /{ }^{39} \mathrm{Ar}$ measurements in Apollo 16 and 17 samples and the chronology of metamorphic and 
volcanic activity in the Taurus-Littrow region. Proceedings, 4th Lunar and Planetary Science Conference. pp. 1725-1756.

Jessberger E. K., Kirsten T., and Staudacher T. 1977. One rock and many ages-Further K-Ar data on consortium breccia 73215. Proceedings, 8th Lunar and Planetary Science Conference. pp. 2567-2580.

Jolliff B. L., Rockow K. M., Korotev R. L., and Haskin L. A. 1996. Lithologic distribution and geologic history of the Apollo 17 site: The record in soils and small rock particles from the highland massifs. Meteoritics \& Planetary Science 31:116-145.

Jolliff B. L., Gillis J. J., Haskin L. A., Korotev R. L., and Wieczorek M. A. 2000. Major lunar crustal terranes: Surface expressions and crust-mantle origins. Journal of Geophysical Research 105:4197-4216.

Kring D. A. 1995. The dimensions of the Chicxulub impact crater and impact melt sheet. Journal of Geophysical Research 100:16979-16986.

Leich D. A., Kahl S. B., Kirschbaum A. R., Niemeyer S., and Phinney D. 1975. Rare gas constraints on the history of Boulder 1, Station 2, Apollo 17. The Moon 14:407-444.

Liu D., Jolliff B. L., Zeigler A. Z., Korotev R. L., Wan Y., Xie H., Zhang Y., Dong Y., and Wang W. 2012. Comparative zircon U-Pb geochronology of impact melt breccias from Apollo 12 and lunar meteorite SaU 169, and implications for the age of the Imbrium impact. Earth and Planetary Science Letters 319:277-286.

Liu J. G., Galenas M. G., Puchtel I. S., and Walker R. J. 2012. Late heavy bombardment of the Moon: Evidence from Os isotope and highly siderophile element characteristics of lunar impact-melt breccias (abstract \#2366). 43rd Lunar and Planetary Science Conference.

Ludwig K. R. 2008. User's Manual for Isoplot 3.60, A geochronological toolkit for Microsoft Excel. Berkeley Geochronological Center Special Publication 4, Berkeley, California: Berkeley Geochronological Center. 77p.

McGetchin T.R., Settle M., and Head J.W. 1973. Radial thickness variation in impact crater ejecta: Implications for lunar basin deposits. Earth and Planetary Science Letters 20:226-236.

Melosh H. J. 1989. Impact Cratering: A Geologic Process. New York: Oxford University Press. 253p.

Meyer C. 2008. 76055 Impact met breccia. The lunar sample compendium, retrieved February 24, 2015, from http://curator.jsc.nasa.gov/lunar/lsc/

Moore H. J., Hodges C. A., and Scott D. H. 1974. Multiringed basins - Illustrated by Orientale and associated features. Proceedings, 5th Lunar and Planetary Science Conference. pp. 71-100. 
Morgan J. W., Ganapathy R., Higuchi H., Krahenbuhl U., and Anders E. 1974. Lunar basinsTentative characterization of projectiles, from meteoritic elements in Apollo 17 boulders. Proceedings, 5th Lunar and Planetary Science Conference. pp. 1703-1736.

Muehlberger W.R., Batson R.M., Cernan E.A., Freeman V.L., Hait M.H., Holt H.E., Howard K.A., Jackson E.D., Larson K.B., Reed V.S., Rennilson J.J., Schmitt H.H., Scott D.H., Sutton R.L., Stuart-Alexander D., Swann G.A., Trask N.J., Ulrich G.E., Wilshire H.G., and Wolfe E.W. 1973. Preliminary geologic investigation of the Apollo 17 landing site. Apollo 17 preliminary science report, NASA SP-330:6-1 to 6-60.

Nakamura N. O. B. O. R. U., Tatsumoto M. I. T. S. U. N. O. B. U., Nunes P. D., Unruh D. M., Schwab A. P., and Wildeman T. R. 1976. 4.4 by-old clast in Boulder 7, Apollo 17A comprehensive chronological study by $\mathrm{U}-\mathrm{Pb}, \mathrm{Rb}-\mathrm{Sr}$ and $\mathrm{Sm}-\mathrm{Nd}$ methods. Proceedings, 7th Lunar and Planetary Science Conference. pp. 2309-2333.

Nemchin A. A., Pidgeon R. T., Healy D., Grange M. L., Whitehouse M. J., and Vaughan J. 2009. The comparative behavior of apatite-zircon U-Pb systems in Apollo 14 breccias: Implications for the thermal history of the Fra Mauro Formation. Meteoritics \& Planetary Science 44:1717-1734.

Öhman T., Losiak A., Kohout T., O’Sullivan K., Thaisen K., and Weider S. 2015. Impact Crater Database (third edition), Lunar and Planetary Institute, Houston, TX. http://www.lpi.usra.edu/lpi/sci_database.shtml.

Palme H., Baddenhausen H., Blum K., Cendales M., Dreibus G., Hofmeister H., Kruse H., Palme C., Spettel B., Vilcsek E., Wanke H., and Kurat G. 1978. New data on lunar samples and achondrites and a comparison of the least fractionated samples from the earth, the moon and the eucrite parent body. Proceedings, 9th Lunar and Planetary Science Conference. pp. 25-27.

Petro N. E. and Pieters C. M. 2008. The lunar-wide effects of basin ejecta distribution on the early megaregolith. Meteoritics \& Planetary Science 4:1517-1529.

Phinney W. C. 1981. Guidebook for the boulders at Station 6, Apollo 17. Lyndon B. Johson Space Center, Curatorial Branch Publication 55, JSC \#17243.

Premo W. R., Tatsumoto M., Misawa K., Nakamura N., and Kita N. I. 1999. Pb-isotopic systematics of lunar highland rocks $(>3.9 \mathrm{Ga})$ : constraints on early lunar evolution. International geology review 41:95-128.

Ryder G. 1993. Catalog of Apollo 17 Rocks. National Aeronautics and Space Administration, Lyndon B. Johnson Space Center.

Ryder G., Stoeser D. B., Marvin U. B., Bower J. F., and Wood J. A. 1975a. Boulder 1, Station 2, Apollo 17: Petrology and petrogenesis. The Moon 14:327-357.

Schaeffer G. A. and Schaeffer O. A. 1977. ${ }^{39} \mathrm{Ar} /{ }^{40} \mathrm{Ar}$ ages of lunar rocks. Proceedings, 8th Lunar and Planetary Science Conference. pp. 2253-2300. 
Scott D. H., Lucchitta B. K., and Carr M. H. 1972. Geologic Maps of the Taurus-Littrow Region of the Moon: Apollo 17 Pre-Mission Maps. US Geological Survey Miscellaneous Geologic Investigations Map I-800.

Sharp M., Gerasimenko I., Loudin L. C., Liu J., James O. B., Puchtel I. S., and Walker R. J. 2014. Characterization of the dominant impactor signature for Apollo 17 impact melt rocks. Geochimica et Cosmochimica Acta 131:62-80.

Simonds C. H. 1975. Thermal regimes in impact melts and the petrology of the Apollo 17 Station 6 boulder. Proceedings, 6th Lunar and Planetary Science Conference. pp. 641672.

Simonds C. H., Phinney W. C., and Warner J. L. 1974. Petrography and classification of Apollo 17 non-mare rocks with emphasis on samples from the Station 6 boulder. Proceedings, 5th Lunar and Planetary Science Conference. pp. 337-353.

Snape J. F., Nemchin A. A., Grange M. L., Bellucci J. J., Thiessen F., and Whitehouse M. J. 2016. Phosphate ages in Apollo 14 breccias: Resolving multiple impact events with high precision U-Pb SIMS analyses. Geochimica et Cosmochimica Acta 174:13-29.

Spudis P. D. 1993. The Geology of Multi-Ring Impact Basins. The Moon and other planets 263, New York Cambridge University Press.

Spudis P. D. and Ryder G. 1981. Apollo 17 impact melts and their relation to the Serenitatis basin. Multi-ring basins: Formation and evolution 1:133-148.

Spudis P. D., Wilhelms D. E., and Robinson M. S. 2011. The Sculptured Hills of the Taurus Highlands: Implications for the relative age of Serenitatis, basin chronologies and the cratering history of the Moon. Journal of Geophysical Research 116:2156-2202.

Stacey J. S. and Kramers J. D. 1975. Approximation of terrestrial lead isotope evolution by a two-stage model. Earth \& Planetary Science Letters 26:207-221..

Stöffler D. and Ryder G. 2001. Stratigraphy and isotope ages of lunar geologic units: chronological standard for the inner solar system. Space Science Review 96:9-54.

Stöffler D., Ryder G., Ivanov B. A., Artemieva N. A., Cintala M. J., and Grieve R. A. 2006. Cratering history and lunar chronology. Reviews in Mineralogy and Geochemistry 60:519-596.

Stuart-Alexander D. and Howard K.A. 1970. Lunar Maria and circular basins: A review. Icarus 12:440-456.

Swindle T. D., Spudis P. D., Taylor G. J., Korotev R. L., and Nichols Jr R. H. 1991. Searching for Crisium Basin ejecta-Chemistry and ages of Luna 20 impact melts. Proceedings, 21st Lunar and Planetary Science Conference. pp. 167-181.

Turner G., Cadogan P. H., and Yonge C. J. 1973. Argon selenochronology. Proceedings, 4th Lunar and Planetary Science Conference. pp. 1889-1914. 
Warner J. L., Phinney W. C., and Simonds C. H. 1976. Apollo 17, Station 6 boulder sample 76255-Absolute petrology of breccia matrix and igneous clasts. Proceedings, 7th Lunar and Planetary Science Conference. pp. 2233-2250.

Warren P. H. and Wasson J. T. 1979. The origin of KREEP. Reviews of Geophysics 17:73-88.

Wilhelms D. E. and McCauley J. F. 1971. Geologic map of the near side of the Moon, US Geological Survey Miscellaneous Geologic Investigations Map I-703.

Wilhelms D. E., McCauley J. F., and Trask N. J. 1987. The Geologic History of the Moon. US Geological Survey Professional Paper 1348.

Whitehouse M. J. and Kamber B. S. 2005. Assigning dates to thin gneissic veins in highgrade metamorphic terranes: a cautionary tale from Akilia, southwest Greenland. Journal of Petrology 46:291-318.

Whitehouse M. J., Kamber B. S., and Moorbath S. 1999. Age significance of U-Th-Pb zircon data from early Archaean rocks of west Greenland-a reassessment based on combined ion-microprobe and imaging studies. Chemical geology 160:201-224.

Winzer S. R., Nava D. F., Schuhmann P. J., Lum R. K. L., Schuhmann S., Lindstrom M. M., and Philpotts J. A. 1977. The Apollo 17 "melt sheet": Chemistry, age and $\mathrm{Rb} / \mathrm{Sr}$ systematics. Earth and Planetary Science Letters 33:389-400.

Wolfe E. W. 1975. Geologic setting of Boulder 1, Station 2, Apollo 17 landing site. The Moon 14:307-314.

Wolfe E. W., Bailey N.G., Lucchitta B. K., Muehlberger W. R., Scott D. H., Sutton R. L., Wilshire H. G. 1981. The Geologic investigation of the Taurus-Littrow valley, Apollo 17 landing site. US Geological Survey Professional Paper 1080:280.

Wood J. A. 1975. The nature and origin of Boulder 1, Station 2, Apollo 17. The Moon 14:505-517. 

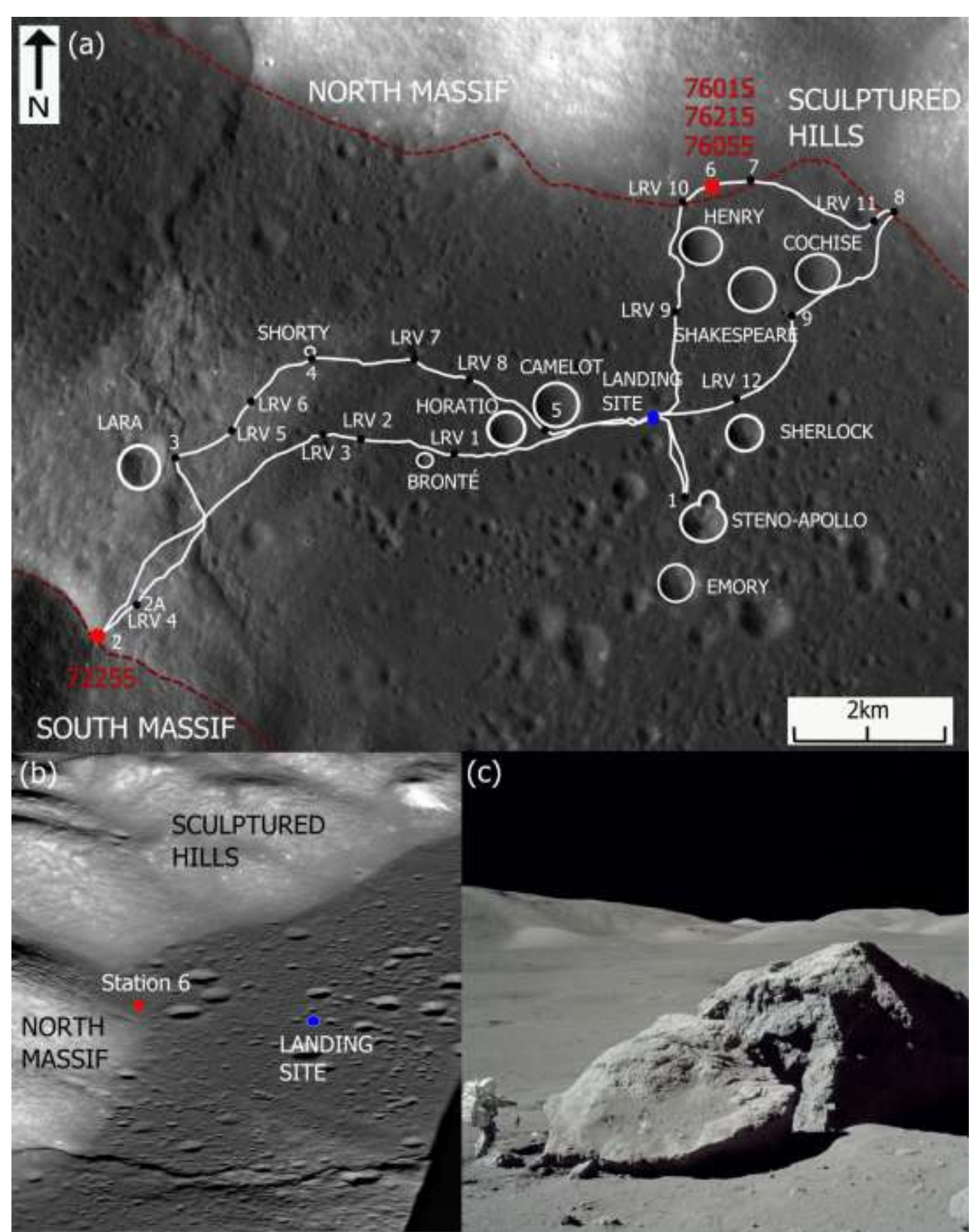

\section{(c)}

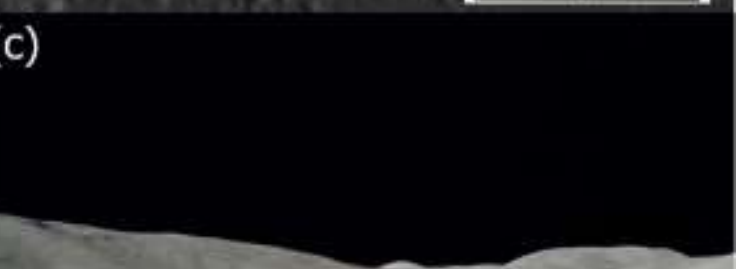

Fig.1. (a) Map showing the Apollo 17 landing site including the sample locations from breccias analyzed in this study (red dots). The blue dot highlights the Apollo 17 landing site and the white lines represent the traverse track. Also outlined are the edges of the North and South Massifs as well at the Sculptured Hills in the eastern part of the landing site. The lunar rover vehicle (LRV) sampling stations are represented as black dots (LRV 1-13) as well as the traverse stations 1-9. The background image is from the Lunar Reconnaissance Orbiter Camera (LROC), frame M104318871 (NASA/GSFC/Arizona State University). (b) View of the Taurus Littrow Valley and the Apollo 17 landing site as captured by LROC. The approximate location of Station 6 is also indicated. The background image is LROC frame M1096343661 (NASA/GSFC/Arizona State University). (c) The large boulder at Station 6 and astronaut Jack Schmitt after collecting samples from the boulder. The image is Apollo image AS17-140-21496. 

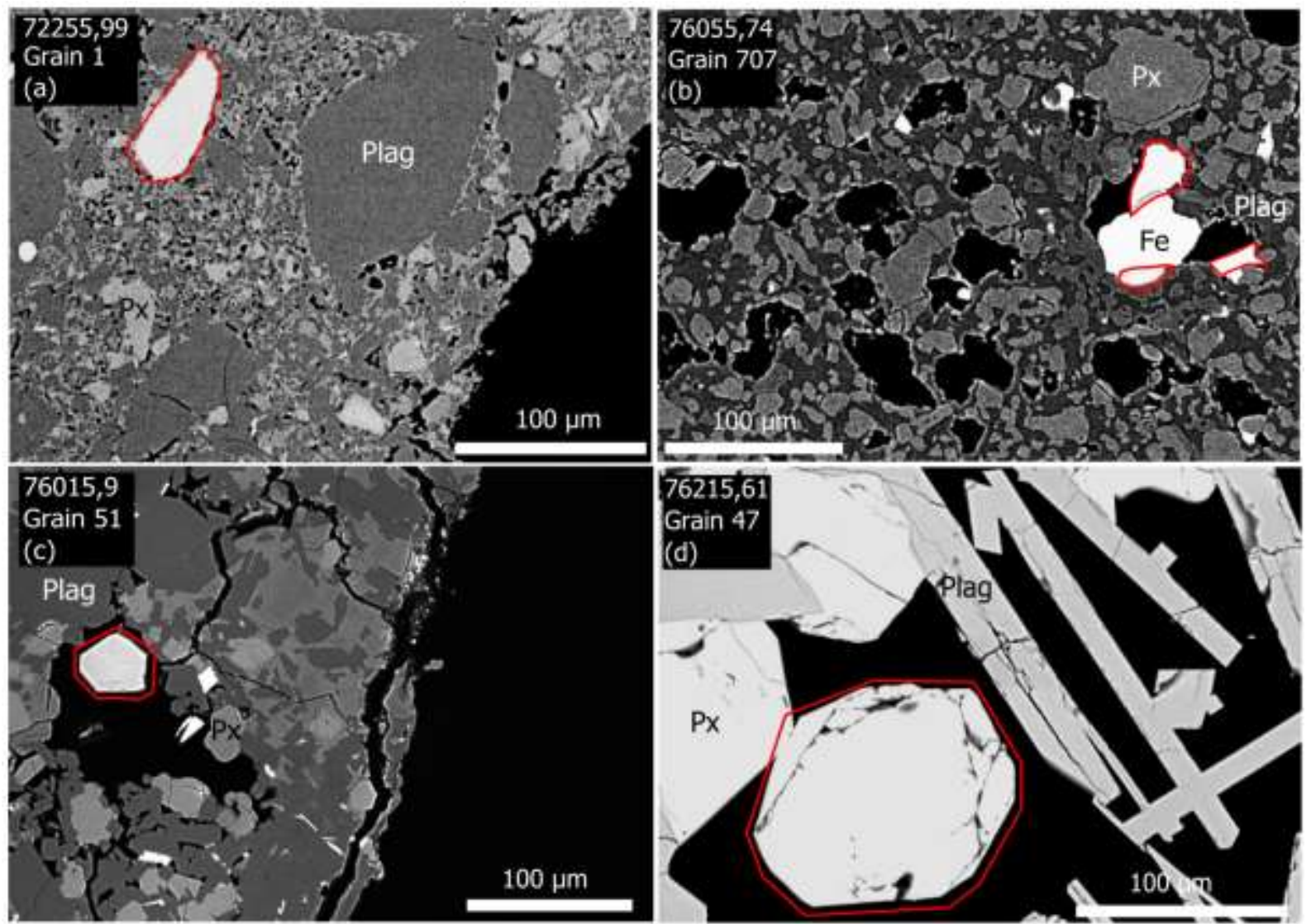

Fig.2. Examples of back scattered electron (BSE) images of the phosphate grains (outlined in red) from each of the analyzed samples. (a) Grain \#1 is a clast occurring in the aphanitic breccia. (b) Two typical phosphate grains (\#707) within the subophitic breccia which occur together with metallic iron. (c) Grain \#51 in the micropoikilitic breccia 76015 is an apatite grain, which is loosely attached to the cavity walls. (d) Grain \#47 is one of the largest apatite grains and yielded the largest spread of ${ }^{207} \mathrm{~Pb} /{ }^{206} \mathrm{~Pb}$ ages, ranging from $3904 \pm 72 \mathrm{Ma}$ at the rim of the grain to $4051 \pm 87 \mathrm{Ma}$ in the center of the grain. Plag=plagioclase, $\mathrm{Fe}=$ metallic iron, $\mathrm{Px}$ $=$ pyroxene. 


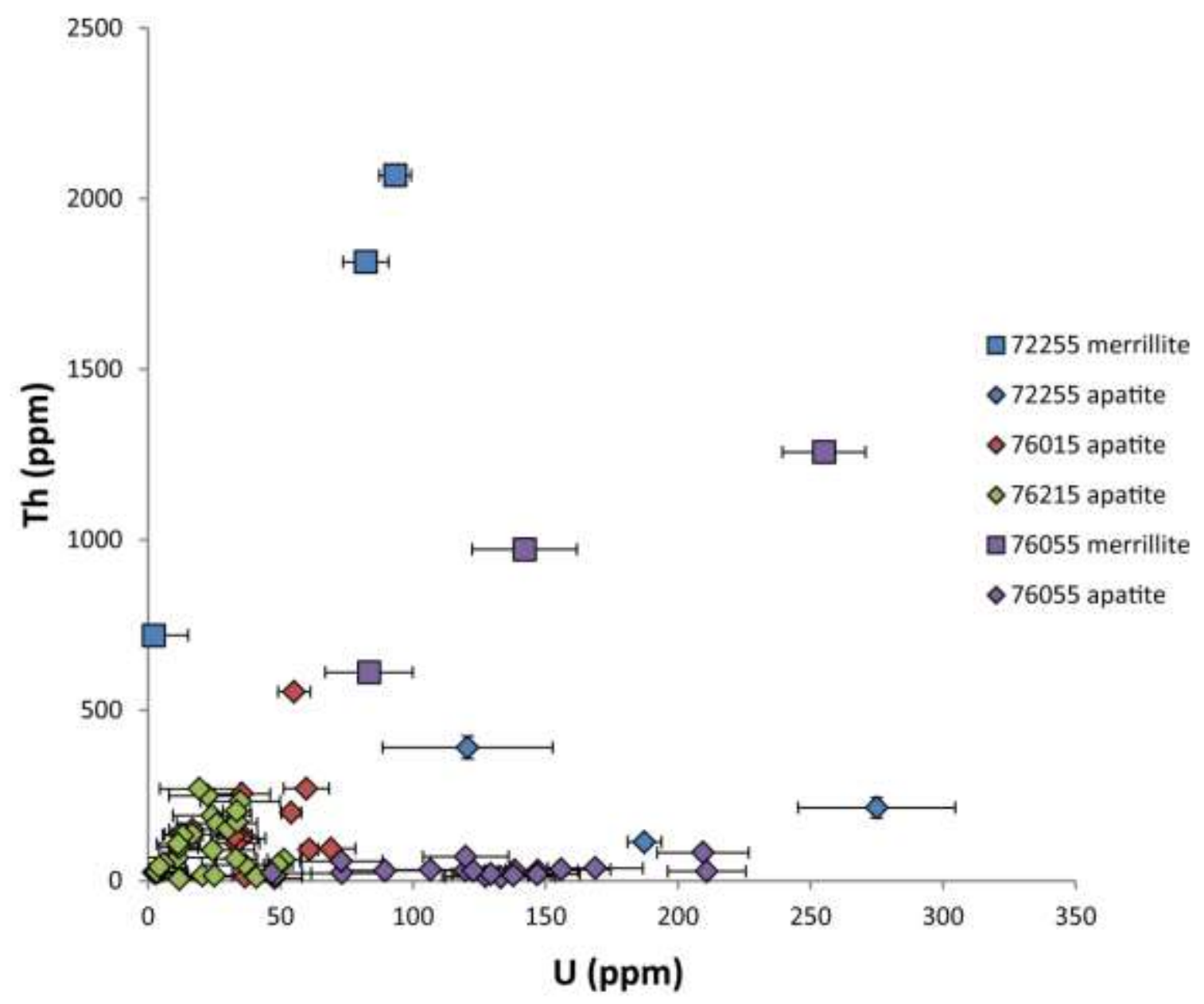

Fig. 3. Th vs U (ppm) plot of all analyzed apatite and merrillite grains. The error bars are $2 \sigma$. 842 

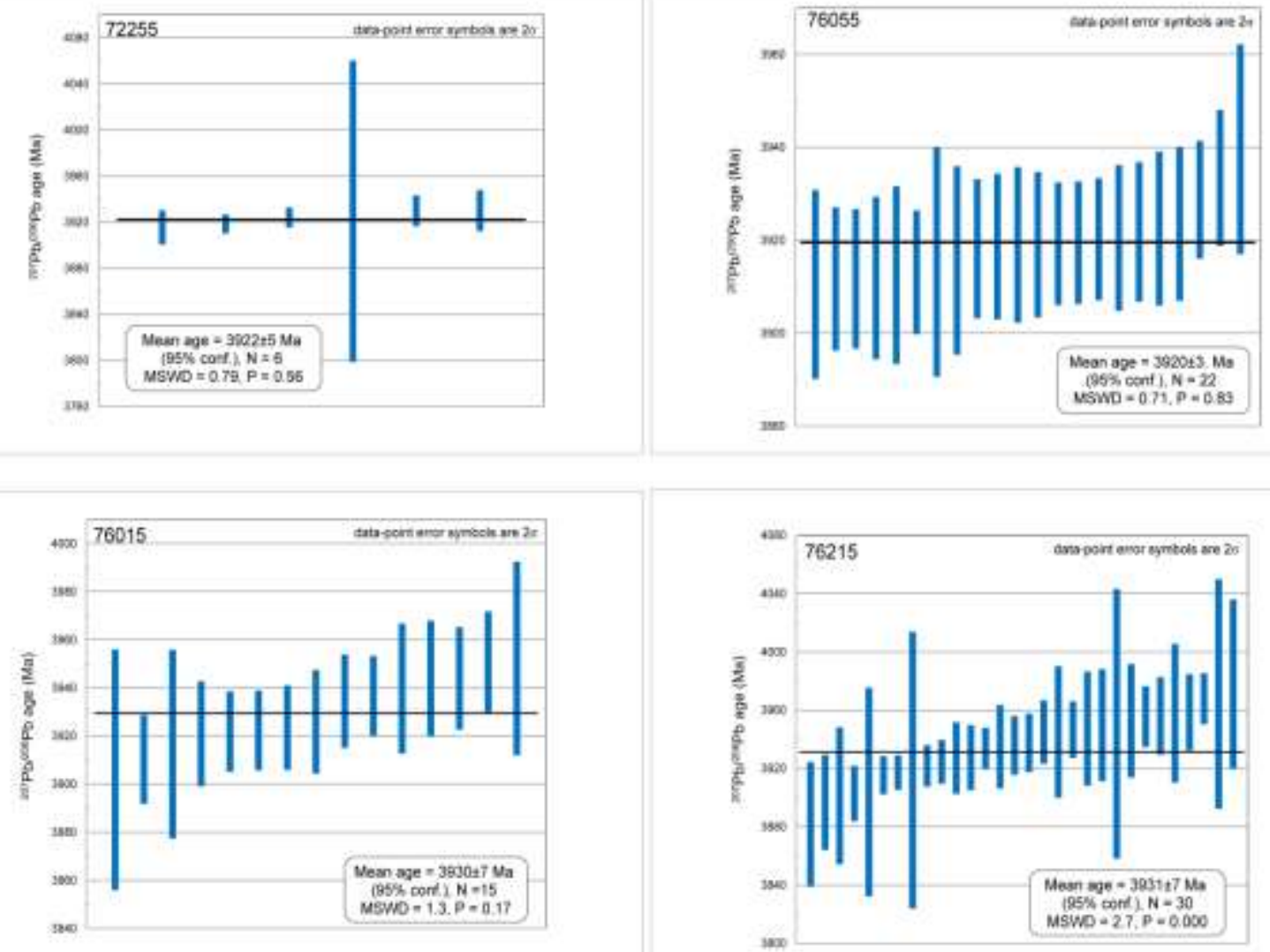

Fig. 4. ${ }^{207} \mathrm{~Pb} /{ }^{206} \mathrm{~Pb}$ ages of phosphates analyzed in the breccias $72255,76055,76015$ and 76215. 


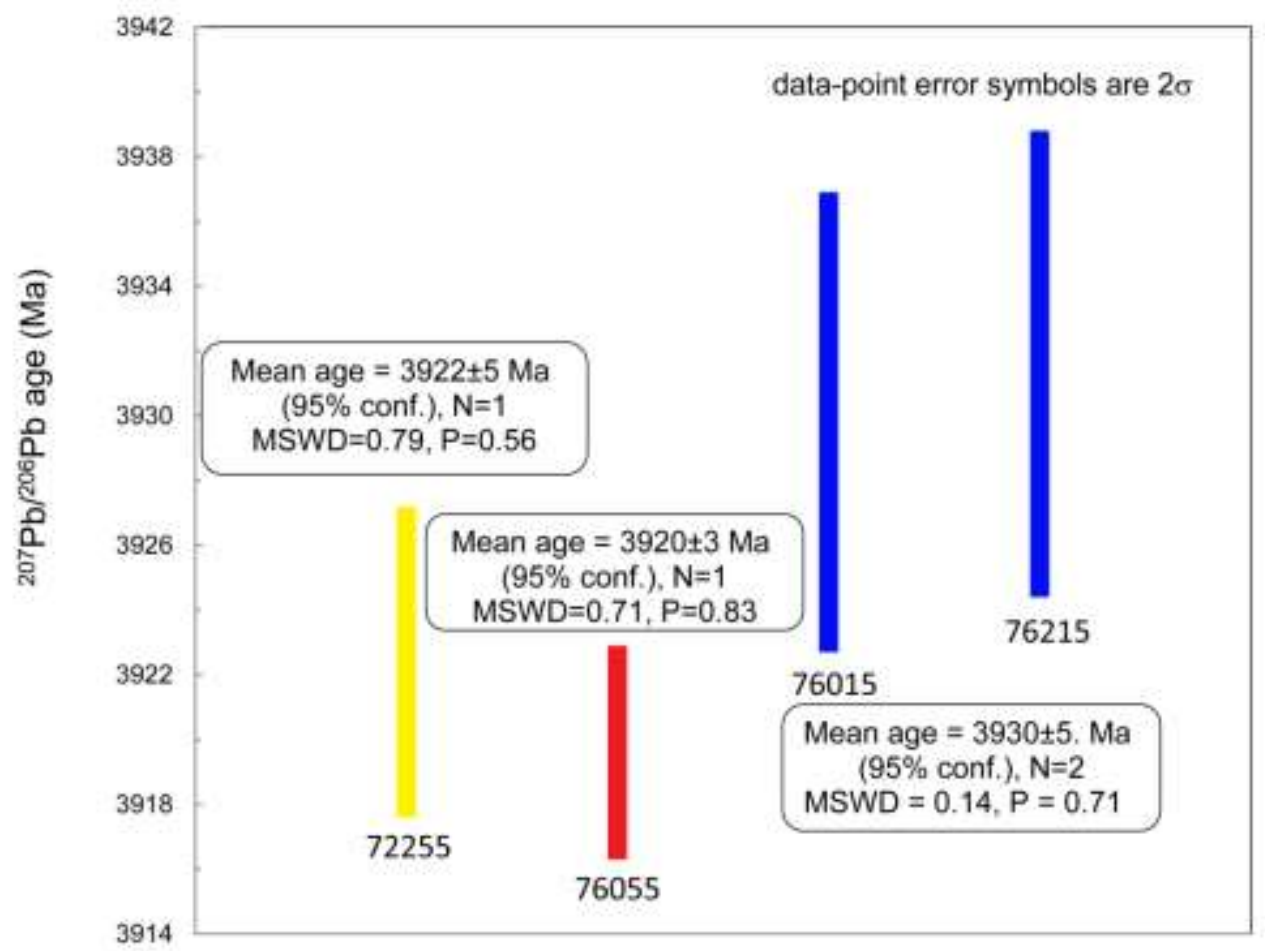

Fig. 5. Comparison of ${ }^{207} \mathrm{~Pb} /{ }^{206} \mathrm{~Pb}$ ages from breccias 72255 (yellow), 76055 (red), 76015 856 (blue) and 76215 (blue). The ${ }^{207} \mathrm{~Pb} /{ }^{206} \mathrm{~Pb}$ age of $3930 \pm 5 \mathrm{Ma}$ is the weighted average age of the two micropoikilitic breccias 76015 and 76215 . 


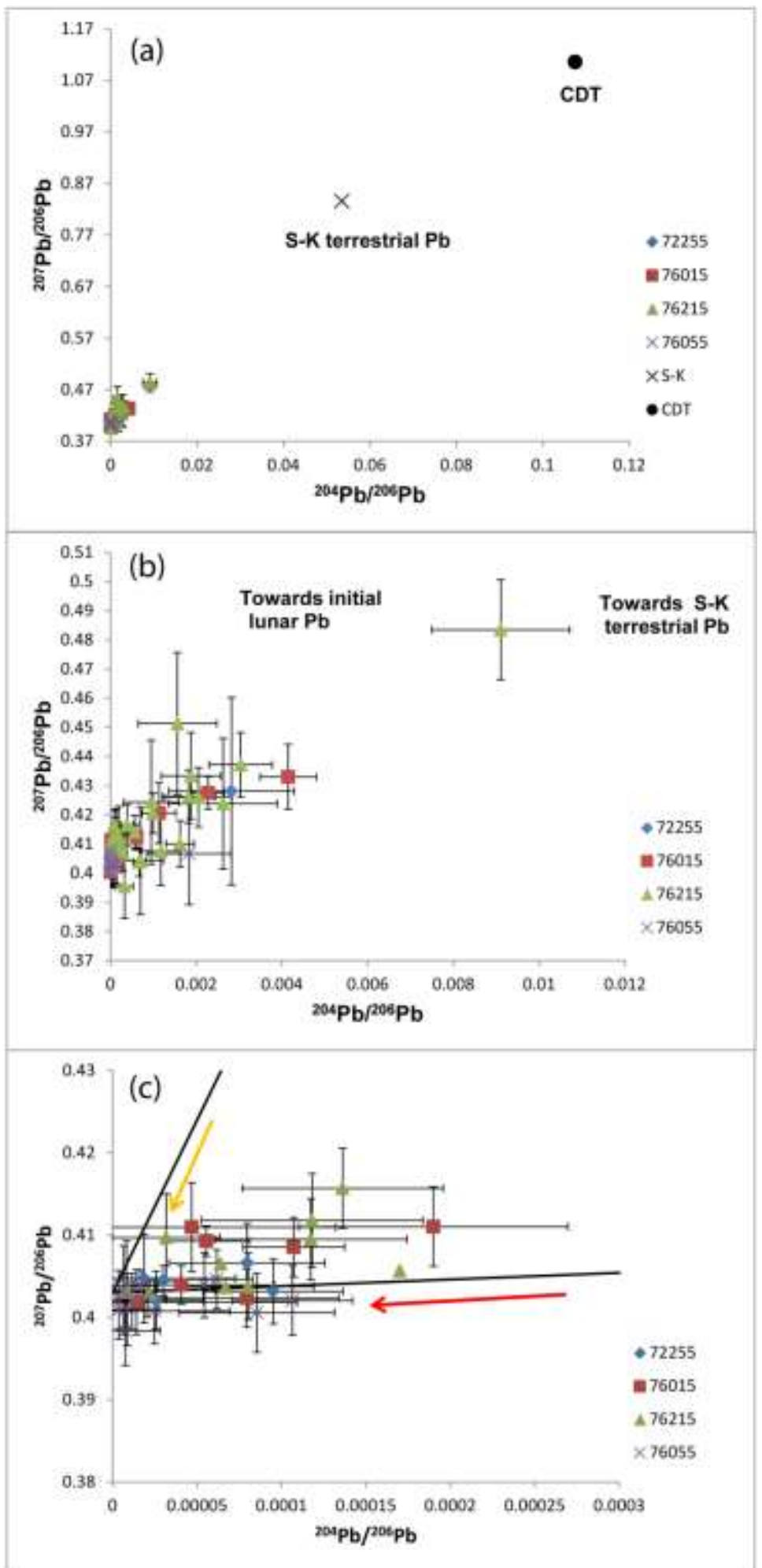

Fig. 6. (a) and (b) ${ }^{207} \mathrm{~Pb} /{ }^{206} \mathrm{~Pb}$ ratios plotted against the ${ }^{204} \mathrm{~Pb} /{ }^{206} \mathrm{~Pb}$ ratios prior to correction for common terrestrial $\mathrm{Pb}$ shown relative to the composition of modern terrestrial $\mathrm{Pb}(\mathrm{S}-\mathrm{K}$ terrestrial $\mathrm{Pb}$; Stacey et al., 1975). Also indicated is the primordial $\mathrm{Pb}$ isotope composition of the Solar System as derived by the Canyon Diablo Troilite (CDT) iron meteorite. The data reveal highly radiogenic composition of the analyzed phosphate grains with minor contribution of initial lunar $\mathrm{Pb}$ or terrestrial common $\mathrm{Pb}$. The trend of phosphate grains with higher ${ }^{206} \mathrm{~Pb} /{ }^{204} \mathrm{~Pb}$ ratios points towards common terrestrial $\mathrm{Pb}$ (Stacey et al., 1975) for which the data has been corrected (c) Only the phosphate grains with ${ }^{204} \mathrm{~Pb} /{ }^{206} \mathrm{~Pb}$ ratios $<0.0002$ are plotted and their trend also indicates common terrestrial $\mathrm{Pb}$ contamination. The yellow arrow shows the correction for common terrestrial $\mathrm{Pb}$ contamination and the red arrow indicates the effect of correcting for initial lunar $\mathrm{Pb}$ ( $\mu$ value $>500$; Premo et al., 1999). 


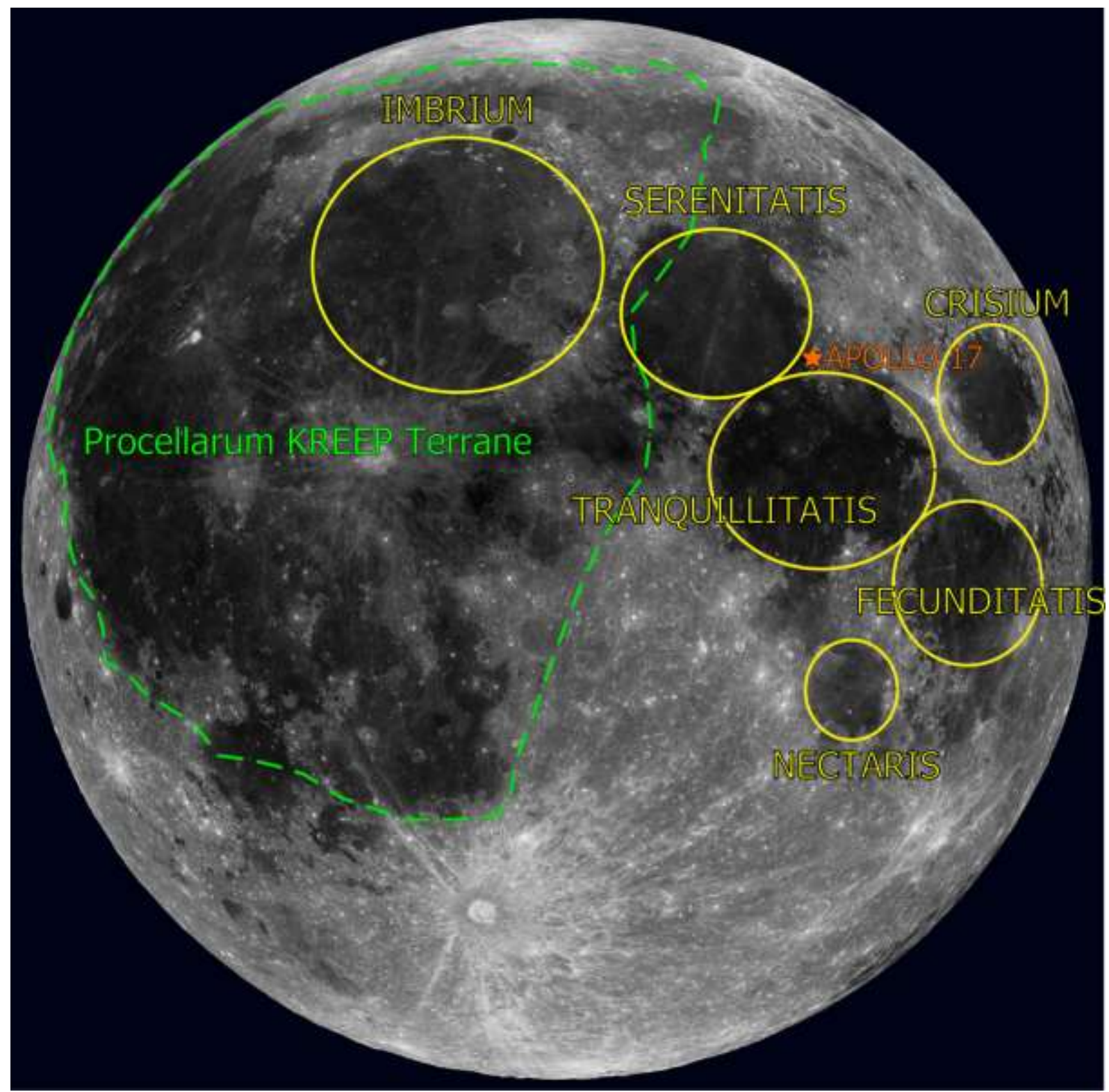

Fig. 7. Location of pre-Nectarian and Nectarian impact craters (yellow circles) with continuous ejecta blankets reaching the Apollo 17 landing site (orange star). The Procellarum KREEP terrane is outlined by dashed green lines (after Jolliff et al., 2000). The background image is from the Lunar Reconnaissance Orbiter Wide Angle Camera mosaic of the lunar nearside (NASA/GSFC/Arizona State University). 


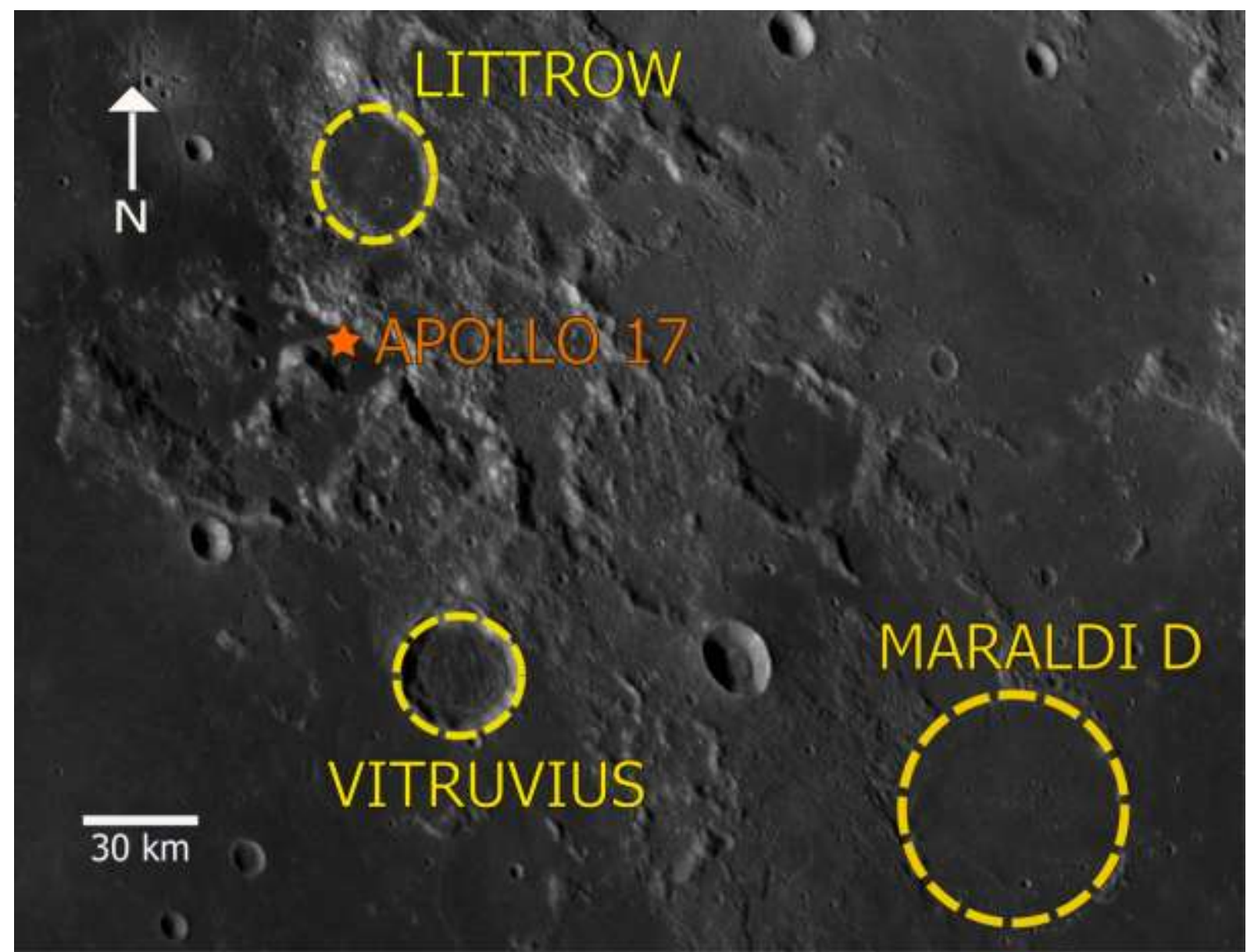

Fig. 8. The location of larger impact craters (dashed yellow circles) in the vicinity of the Apollo 17 landing site (orange dot).Only the continuous ejecta blanket of the crater Littrow reaches the North Massif at the Apollo 17 landing site, and is therefore a possible source for the breccias sampled at the North Massif. The background image is a part from the Lunar Reconnaissance Orbiter Wide Angle mosaic of the lunar nearside (NASA/GSFC/Arizona State University). 
Table 1. All SIMS data obtained for

the four samples.

\begin{tabular}{|c|c|c|c|c|c|c|c|c|c|c|c|c|c|c|c|c|c|}
\hline $\begin{array}{l}\text { Sample/Spot } \\
\#\end{array}$ & $\begin{array}{c}\mathrm{U} \\
(\mathrm{ppm})\end{array}$ & $\begin{array}{l} \pm 2 \sigma \\
(\%)\end{array}$ & $\begin{array}{c}\text { Th } \\
\text { (ppm) }\end{array}$ & $\begin{array}{l} \pm 2 \sigma \\
(\%)\end{array}$ & $\mathrm{Th} / \mathrm{U}$ & $\begin{array}{l} \pm 2 \sigma \\
(\%)\end{array}$ & $\begin{array}{c}{ }^{206} \mathrm{~Pb} /{ }^{204} \\
\mathrm{~Pb} \\
\text { measured }\end{array}$ & ${ }^{207} \mathrm{~Pb} /{ }^{206} \mathrm{~Pb}$ & $\begin{array}{l} \pm 2 \sigma \\
(\%)\end{array}$ & ${ }^{207} \mathrm{~Pb} /{ }^{235} \mathrm{U}$ & $\begin{array}{l} \pm 2 \sigma \\
(\%)\end{array}$ & ${ }^{206} \mathrm{~Pb} /{ }^{238} \mathrm{U}$ & $\begin{array}{l} \pm 2 \sigma \\
(\%)\end{array}$ & $\rho$ & $\begin{array}{c}{ }^{207} \mathrm{~Pb} /{ }^{206} \mathrm{~Pb} \\
\text { age }(\mathrm{Ma})\end{array}$ & $\begin{array}{l} \pm 2 \sigma \\
(\mathrm{Ma})\end{array}$ & Mineral \\
\hline \multicolumn{18}{|l|}{72255,99} \\
\hline 1,1 & 93.28 & 5.83 & 2068.59 & 5.97 & 22.18 & 1.31 & 12057 & 0.4024 & 0.98 & 48.35 & 7.33 & 0.8729 & 7.26 & 0.99 & 3916 & 15 & Merrillite \\
\hline 1,2 & 82.19 & 8.53 & 1814.57 & 8.58 & 22.08 & 0.97 & 14082 & 0.4062 & 1.18 & 42.16 & 7.31 & 0.7538 & 7.22 & 0.99 & 3930 & 18 & Merrillite \\
\hline \multicolumn{18}{|l|}{72255,125} \\
\hline 27,1 & 187.38 & 6.38 & 113.51 & 6.67 & 0.61 & 1.93 & 32043 & 0.4056 & 0.90 & 45.17 & 7.26 & 0.8078 & 7.21 & 0.99 & 3930 & 13 & Apatite \\
\hline 34,1 & 2.23 & 11.72 & 719.55 & 12.91 & 323.00 & 5.40 & 355 & 0.4055 & 8.91 & 46.99 & 11.88 & 0.8405 & 7.85 & 0.66 & 3930 & 131 & Merrillite \\
\hline \multicolumn{18}{|l|}{72255,306} \\
\hline 1,1 & 275.00 & 29.61 & 214.19 & 29.67 & 1.78 & 0.89 & 48046 & 0.4027 & 0.54 & 52.26 & 5.27 & 0.9417 & 5.24 & 0.99 & 3918 & 8 & Apatite \\
\hline 68,1 & 120.66 & 32.09 & 390.60 & 33.12 & 8.17 & 4.08 & 67019 & 0.4041 & 0.57 & 49.38 & 5.76 & 0.8865 & 5.74 & 1.00 & 3924 & 9 & Apatite \\
\hline \multicolumn{18}{|l|}{76055,74} \\
\hline 266,1 & 255.09 & 15.60 & 1257.00 & 15.81 & 6.37 & 2.61 & 26186 & 0.4028 & 0.88 & 52.98 & 7.24 & 0.9540 & 7.18 & 0.99 & 3919 & 13 & Merrillite \\
\hline 268,1 & 83.41 & 16.52 & 611.19 & 16.65 & 6.93 & 2.06 & 18157 & 0.4017 & 1.35 & 56.85 & 7.98 & 1.0263 & 7.87 & 0.99 & 3916 & 20 & Merrillite \\
\hline 495,1 & 142.08 & 19.71 & 971.38 & 19.83 & 5.35 & 2.16 & 25625 & 0.4030 & 1.05 & 49.99 & 7.71 & 0.8995 & 7.64 & 0.99 & 3920 & 16 & Merrillite \\
\hline 578,1 & 209.42 & 17.25 & 82.52 & 17.38 & 0.46 & 2.13 & * & 0.4039 & 1.11 & 48.21 & 8.04 & 0.8658 & 7.96 & 0.99 & 3924 & 17 & Apatite \\
\hline 627,1 & 127.34 & 16.29 & 12.64 & 16.47 & 0.09 & 2.44 & 6682 & 0.4017 & 1.65 & 46.24 & 7.51 & 0.8350 & 7.33 & 0.98 & 3915 & 25 & Apatite \\
\hline 627,2 & 133.09 & 20.76 & 10.05 & 21.21 & 0.15 & 4.31 & $*$ & 0.4027 & 1.04 & 46.75 & 7.42 & 0.8421 & 7.34 & 0.99 & 3919 & 16 & Apatite \\
\hline 627,4 & 147.15 & 15.04 & 29.58 & 15.11 & 0.21 & 1.48 & $*$ & 0.4027 & 0.88 & 44.02 & 7.26 & 0.7927 & 7.21 & 0.99 & 3919 & 13 & Apatite \\
\hline 627,5 & 138.36 & 15.84 & 30.53 & 15.94 & 0.18 & 1.74 & $*$ & 0.4027 & 1.12 & 41.24 & 7.33 & 0.7429 & 7.25 & 0.99 & 3919 & 17 & Apatite \\
\hline 627,7 & 210.81 & 14.69 & 27.60 & 14.75 & 0.19 & 1.39 & $*$ & 0.4030 & 0.88 & 45.75 & 7.27 & 0.8234 & 7.22 & 0.99 & 3920 & 13 & Apatite \\
\hline 627,8 & 146.89 & 16.10 & 19.00 & 16.21 & 0.16 & 1.90 & $*$ & 0.4034 & 1.00 & 42.91 & 7.25 & 0.7715 & 7.18 & 0.99 & 3922 & 15 & Apatite \\
\hline 627,9 & 119.78 & 15.03 & 30.33 & 15.12 & 0.19 & 1.71 & * & 0.4007 & 1.00 & 38.68 & 7.60 & 0.7002 & 7.54 & 0.99 & 3912 & 15 & Apatite \\
\hline
\end{tabular}




\begin{tabular}{|c|c|c|c|c|c|c|c|c|c|c|c|c|c|c|c|c|c|}
\hline 654,1 & 155.94 & 18.58 & 32.97 & 18.69 & 0.37 & 2.08 & 13811 & 0.4024 & 1.00 & 45.36 & 7.49 & 0.8176 & 7.42 & 0.99 & 3918 & 15 & Apatite \\
\hline 654,2 & 89.50 & 17.90 & 29.54 & 17.96 & 0.52 & 1.43 & $*$ & 0.4004 & 1.36 & 38.59 & 7.40 & 0.6990 & 7.27 & 0.98 & 3910 & 20 & Apatite \\
\hline 706,2 & 46.74 & 14.86 & 22.19 & 15.13 & 0.30 & 2.84 & $*$ & 0.4082 & 1.51 & 43.56 & 7.34 & 0.7740 & 7.19 & 0.98 & 3940 & 23 & Apatite \\
\hline 706,3 & 73.16 & 14.92 & 22.47 & 15.22 & 0.31 & 3.03 & $*$ & 0.4009 & 1.27 & 41.54 & 7.30 & 0.7514 & 7.19 & 0.98 & 3913 & 19 & Apatite \\
\hline 707,1 & 72.93 & 15.62 & 57.30 & 15.90 & 0.42 & 2.96 & $*$ & 0.4011 & 0.89 & 45.67 & 7.25 & 0.8258 & 7.20 & 0.99 & 3913 & 13 & Apatite \\
\hline 707,2 & 137.83 & 14.67 & 15.36 & 14.82 & 0.14 & 2.11 & $*$ & 0.4036 & 1.11 & 37.68 & 7.37 & 0.6771 & 7.29 & 0.99 & 3923 & 17 & Apatite \\
\hline 719,1 & 129.33 & 14.50 & 19.96 & 14.62 & 0.19 & 1.88 & $*$ & 0.4007 & 1.17 & 38.15 & 7.44 & 0.6904 & 7.35 & 0.99 & 3912 & 17 & Apatite \\
\hline 719,2 & 106.56 & 15.31 & 31.91 & 15.39 & 0.26 & 1.61 & $*$ & 0.4065 & 0.98 & 45.90 & 7.30 & 0.8188 & 7.23 & 0.99 & 3933 & 15 & Apatite \\
\hline 719,3 & 122.80 & 14.59 & 29.66 & 14.68 & 0.25 & 1.62 & $*$ & 0.4007 & 1.03 & 54.12 & 7.27 & 0.9795 & 7.20 & 0.99 & 3912 & 15 & Apatite \\
\hline 719,4 & 119.92 & 16.15 & 70.66 & 16.32 & 0.42 & 2.34 & $*$ & 0.4026 & 1.04 & 41.63 & 7.26 & 0.7501 & 7.19 & 0.99 & 3919 & 16 & Apatite \\
\hline 719,5 & 168.79 & 17.95 & 36.84 & 18.02 & 0.24 & 1.56 & $*$ & 0.4053 & 0.85 & 47.36 & 7.33 & 0.8476 & 7.28 & 0.99 & 3929 & 13 & Apatite \\
\hline \multicolumn{18}{|c|}{76015,9} \\
\hline 23,1 & 13.28 & 3.66 & 117.79 & 5.84 & 8.87 & 4.55 & 241 & 0.3992 & 3.36 & 40.20 & 5.96 & 0.7305 & 4.92 & 0.83 & 3906 & 50 & Apatite \\
\hline 51,1 & 35.77 & 3.45 & 134.00 & 3.76 & 3.75 & 1.49 & 153 & 0.4020 & 2.63 & 44.93 & 6.37 & 0.8106 & 5.80 & 0.91 & 3917 & 39 & Apatite \\
\hline 53,1 & 55.17 & 6.04 & 554.01 & 6.17 & 10.04 & 1.26 & 6706 & 0.4034 & 1.11 & 50.90 & 4.62 & 0.9151 & 4.48 & 0.97 & 3922 & 17 & Apatite \\
\hline 57,1 & 9.81 & 4.28 & 67.35 & 4.76 & 6.87 & 2.09 & 885 & 0.4117 & 2.70 & 54.65 & 5.20 & 0.9629 & 4.45 & 0.85 & 3952 & 40 & Apatite \\
\hline 57,2 & 60.89 & 3.33 & 91.33 & 4.40 & 1.50 & 2.87 & 1648 & 0.4075 & 1.11 & 51.93 & 4.58 & 0.9243 & 4.45 & 0.97 & 3937 & 17 & Apatite \\
\hline 57,3 & 54.07 & 3.83 & 200.19 & 4.06 & 3.70 & 1.36 & 439 & 0.4094 & 1.61 & 43.93 & 5.34 & 0.7783 & 5.10 & 0.95 & 3944 & 24 & Apatite \\
\hline \multicolumn{18}{|c|}{76015,98} \\
\hline 6,1 & 47.75 & 10.35 & 7.61 & 11.51 & 0.16 & 5.05 & $*$ & 0.4003 & 1.23 & 45.21 & 4.61 & 0.8192 & 4.44 & 0.96 & 3910 & 18 & Apatite \\
\hline 17,1 & 35.29 & 9.04 & 123.67 & 9.55 & 3.50 & 3.09 & 7096 & 0.4094 & 1.42 & 46.07 & 4.74 & 0.8161 & 4.52 & 0.95 & 3944 & 21 & Apatite \\
\hline 22,1 & 69.02 & 9.19 & 93.84 & 9.37 & 1.36 & 1.84 & 5696 & 0.4035 & 1.11 & 43.56 & 4.64 & 0.7830 & 4.51 & 0.97 & 3922 & 17 & Apatite \\
\hline 64,1 & 16.84 & 8.76 & 150.24 & 8.95 & 8.92 & 1.82 & 10577 & 0.4082 & 1.81 & 52.55 & 5.07 & 0.9336 & 4.73 & 0.93 & 3940 & 27 & Apatite \\
\hline 68,2 & 35.51 & 10.54 & 254.87 & 10.60 & 7.18 & 1.12 & 27558 & 0.4068 & 1.29 & 49.89 & 4.70 & 0.8895 & 4.52 & 0.96 & 3934 & 19 & Apatite \\
\hline 68,3 & 59.82 & 8.60 & 270.22 & 8.71 & 4.52 & 1.40 & 30390 & 0.4039 & 1.17 & 50.25 & 4.68 & 0.9024 & 4.53 & 0.97 & 3923 & 18 & Apatite \\
\hline 69,1 & 36.60 & 10.37 & 11.78 & 10.56 & 0.32 & 1.99 & 15694 & 0.4032 & 1.46 & 42.90 & 4.68 & 0.7716 & 4.45 & 0.95 & 3921 & 22 & Apatite \\
\hline 70,1 & 33.33 & 8.75 & 109.41 & 8.89 & 3.28 & 1.57 & 48824 & 0.4112 & 1.40 & 47.91 & 4.78 & 0.8450 & 4.57 & 0.96 & 3951 & 21 & Apatite \\
\hline 70,2 & 32.66 & 8.64 & 130.80 & 8.72 & 4.01 & 1.14 & 5169 & 0.4045 & 1.44 & 50.47 & 4.87 & 0.9049 & 4.65 & 0.96 & 3926 & 22 & Apatite \\
\hline
\end{tabular}




\section{5,57}

\begin{tabular}{|c|c|c|c|c|c|c|c|c|c|c|c|c|c|c|c|c|c|}
\hline 6,1 & 36.69 & 16.31 & 46.79 & 18.74 & 1.28 & 9.23 & 1490 & 0.3983 & 1.26 & 46.64 & 5.36 & 0.8492 & 5.21 & 0.97 & 3903 & 19 & Apatite \\
\hline 12,1 & 11.07 & 14.76 & 67.65 & 14.85 & 7.88 & 1.17 & 2572 & 0.4134 & 1.75 & 48.82 & 5.39 & 0.8564 & 5.09 & 0.95 & 3959 & 26 & Apatite \\
\hline 12,2 & 24.24 & 14.74 & 191.06 & 14.79 & 6.66 & 1.14 & 10172 & 0.4072 & 1.35 & 49.57 & 5.10 & 0.8828 & 4.92 & 0.96 & 3936 & 20 & Apatite \\
\hline 12,3 & 34.87 & 15.00 & 232.32 & 15.05 & 3.48 & 0.57 & 15670 & 0.4042 & 1.01 & 51.54 & 5.21 & 0.9250 & 5.11 & 0.98 & 3925 & 15 & Apatite \\
\hline 13,2 & 24.35 & 15.87 & 90.18 & 14.67 & 11.02 & 4.04 & 11675 & 0.4160 & 1.17 & 52.42 & 5.05 & 0.9139 & 4.91 & 0.97 & 3968 & 17 & Apatite \\
\hline 13,3 & 22.62 & 14.64 & 249.19 & 15.19 & 13.86 & 2.45 & 4291 & 0.4077 & 1.34 & 50.47 & 5.15 & 0.8979 & 4.97 & 0.97 & 3938 & 20 & Apatite \\
\hline 13,4 & 19.44 & 14.96 & 269.55 & 15.16 & 6.45 & 7.36 & 9380 & 0.4126 & 1.39 & 47.68 & 5.13 & 0.8381 & 4.94 & 0.96 & 3956 & 21 & Apatite \\
\hline 13,5 & 26.03 & 15.20 & 167.96 & 16.89 & 1.59 & 1.64 & $*$ & 0.4101 & 1.29 & 50.59 & 5.10 & 0.8946 & 4.94 & 0.97 & 3947 & 19 & Apatite \\
\hline 32,1 & 12.01 & 14.71 & 8.81 & 15.48 & 0.73 & 4.81 & 1007 & 0.4127 & 1.78 & 49.96 & 5.22 & 0.8780 & 4.90 & 0.94 & 3956 & 27 & Apatite \\
\hline \multicolumn{18}{|c|}{76215,10} \\
\hline 17,1 & 48.31 & 2.73 & 17.64 & 3.35 & 0.37 & 1.95 & 84456 & 0.4022 & 0.79 & 47.53 & 3.13 & 0.8571 & 3.03 & 0.97 & 3917 & 12 & Apatite \\
\hline 17,3 & 40.90 & 3.09 & 11.08 & 3.48 & 0.27 & 1.60 & 14450 & 0.4017 & 0.87 & 49.73 & 3.50 & 0.8980 & 3.39 & 0.97 & 3915 & 13 & Apatite \\
\hline 20,1 & 30.12 & 3.01 & 151.79 & 3.49 & 5.04 & 1.76 & 19736 & 0.4066 & 0.95 & 48.81 & 3.27 & 0.8707 & 3.13 & 0.96 & 3934 & 14 & Apatite \\
\hline 20,2 & 33.61 & 2.37 & 172.17 & 3.30 & 5.12 & 2.29 & 100000 & 0.4034 & 0.95 & 45.42 & 3.10 & 0.8166 & 2.95 & 0.95 & 3922 & 14 & Apatite \\
\hline \multicolumn{18}{|c|}{76215,61} \\
\hline $47,1^{1}$ & 2.29 & 10.06 & 24.13 & 10.93 & 10.52 & 4.27 & 641 & 0.4398 & 5.91 & 57.70 & 7.55 & 0.9517 & 4.69 & 0.62 & 4051 & 87 & Apatite \\
\hline 47,3 & 2.92 & 10.39 & 21.49 & 11.08 & 7.36 & 3.86 & 381 & 0.4026 & 6.43 & 40.47 & 8.40 & 0.7291 & 5.41 & 0.64 & 3919 & 95 & Apatite \\
\hline 47,4 & 4.09 & 10.74 & 26.96 & 11.23 & 6.58 & 3.27 & 1429 & 0.3986 & 4.82 & 41.37 & 6.74 & 0.7528 & 4.72 & 0.70 & 3904 & 72 & Apatite \\
\hline 47,5 & 3.32 & 8.26 & 25.65 & 9.59 & 7.73 & 4.86 & 1056 & 0.4169 & 5.34 & 46.77 & 7.05 & 0.8137 & 4.60 & 0.65 & 3971 & 79 & Apatite \\
\hline 49,1 & 11.87 & 6.45 & 4.80 & 9.19 & 0.40 & 6.54 & 330 & 0.4132 & 3.20 & 45.95 & 6.25 & 0.8065 & 5.36 & 0.86 & 3958 & 48 & Apatite \\
\hline 50,1 & 51.47 & 6.35 & 61.24 & 6.49 & 1.19 & 1.36 & 1774 & 0.4097 & 1.45 & 46.75 & 4.67 & 0.8277 & 4.44 & 0.95 & 3945 & 22 & Apatite \\
\hline 50,2 & 49.17 & 5.46 & 46.83 & 5.66 & 0.95 & 1.50 & 6676 & 0.4049 & 1.49 & 45.49 & 4.79 & 0.8148 & 4.55 & 0.95 & 3928 & 22 & Apatite \\
\hline 50,3 & 33.25 & 8.03 & 64.21 & 9.09 & 1.93 & 4.25 & 7700 & 0.4069 & 1.91 & 38.16 & 4.85 & 0.6801 & 4.45 & 0.92 & 3935 & 29 & Apatite \\
\hline 50,4 & 5.95 & 8.16 & 50.58 & 9.15 & 8.50 & 4.14 & 110 & 0.4113 & 6.27 & 53.45 & 19.82 & 0.9427 & 18.80 & 0.95 & 3951 & 92 & Apatite \\
\hline 53,1 & 16.82 & 7.01 & 136.24 & 10.15 & 8.10 & 7.34 & 488 & 0.4097 & 3.03 & 51.57 & 7.51 & 0.9130 & 6.87 & 0.92 & 3945 & 45 & Apatite \\
\hline 53,2 & 33.53 & 5.15 & 204.41 & 5.33 & 6.10 & 1.38 & 3510 & 0.4048 & 1.64 & 52.80 & 4.85 & 0.9459 & 4.57 & 0.94 & 3927 & 25 & Apatite \\
\hline
\end{tabular}




\begin{tabular}{|c|c|c|c|c|c|c|c|c|c|c|c|c|c|c|c|c|c|}
\hline 56,1 & 20.59 & 5.35 & 16.01 & 5.79 & 0.78 & 2.20 & 617 & 0.3968 & 2.18 & 47.08 & 4.96 & 0.8606 & 4.45 & 0.90 & 3897 & 33 & Apatite \\
\hline 56,2 & 25.08 & 6.82 & 14.87 & 7.38 & 0.59 & 2.83 & 548 & 0.4118 & 2.61 & 44.35 & 5.82 & 0.7811 & 5.21 & 0.89 & 3953 & 39 & Apatite \\
\hline 58,1 & 12.17 & 5.86 & 136.24 & 7.09 & 11.19 & 3.99 & 5245 & 0.4110 & 2.58 & 50.60 & 5.43 & 0.8930 & 4.78 & 0.88 & 3950 & 38 & Apatite \\
\hline 58,2 & 11.61 & 7.30 & 96.68 & 8.48 & 8.32 & 4.30 & 852 & 0.3979 & 3.15 & 39.66 & 5.44 & 0.7229 & 4.44 & 0.82 & 3901 & 47 & Apatite \\
\hline 58,3 & 13.13 & 7.62 & 132.89 & 8.24 & 10.12 & 3.14 & 7661 & 0.4103 & 2.63 & 46.76 & 5.45 & 0.8266 & 4.77 & 0.88 & 3947 & 39 & Apatite \\
\hline 58,4 & 11.43 & 8.13 & 107.79 & 8.37 & 9.43 & 2.00 & 3067 & 0.3928 & 2.86 & 40.42 & 5.50 & 0.7464 & 4.70 & 0.85 & 3882 & 43 & Apatite \\
\hline 59,1 & 4.36 & 6.89 & 41.27 & 7.63 & 9.47 & 3.29 & 533 & 0.4187 & 3.92 & 59.39 & 6.69 & 1.0286 & 5.42 & 0.81 & 3978 & 58 & Apatite \\
\hline
\end{tabular}

1 The data was removed from the average

${ }^{207} \mathrm{~Pb} /{ }^{206} \mathrm{~Pb}$ average age for the whole sample.

905 Table 1. All SIMS data obtained for the four samples. 
Table 2. Summary table. All errors are shown with $2 \sigma$.

\begin{tabular}{cccc}
\hline Breccia & Texture & Sampling location & $\begin{array}{c}{ }^{207} \mathrm{~Pb} /{ }^{206} \mathrm{~Pb} \\
\text { age }[\mathrm{Ma}]\end{array}$ \\
\hline 72255 & aphanitic & $\begin{array}{c}\text { South Massif, Station 2 } \\
\text { North Massif, 10-15 m }\end{array}$ & $3922 \pm 5$ \\
76055 & subophitic & $\begin{array}{c}\text { away from the Station 6 } \\
\text { boulder }\end{array}$ & $3920 \pm 3$ \\
76015 & micropoikilitic & North Massif, Station 6 & $3930 \pm 7$ \\
76215 & micropoikilitic & North Masssif, Station 6 & $3931 \pm 7$
\end{tabular}

906

907 Appendix

908 Table A1. Calculation of the ejecta distribution and thickness of ejecta deposits for basins and 909 impact craters, which might have contributed material to the Apollo 17 landing site.

910

911

Fig. A1. Tera Wasserburg concordia diagrams for each of the analyzed samples.

912

913

914

915

Fig. A2. Conventional U-Pb concordia diagrams for each of the analyzed samples.

916

Fig. A3a-d. BSE images of all Ca-phosphate grains analyzed in this study (outlined in red).

917 $\mathrm{Plag}=$ plagioclase, $\mathrm{Fe}=$ metallic iron, $\mathrm{Px}=$ pyroxene, $\mathrm{Ilm}=$ ilmenite. 